\title{
Stressing diabetes? The hidden links between insulinotropic peptides and the HPA axis
}

\author{
Yolanda Diz-Chaves',2, Manuel Gil-Lozano1,2, Laura Toba',2, Juan Fandiño1,2, \\ Hugo Ogando1,2, Lucas C González-Matías',2 and Federico Mallo1,2 \\ 1Laboratory of Endocrinology, Center for Biomedical Research - CINBIO, University of Vigo, Vigo, Spain \\ 2Instituto de Investigación Sanitaria Galicia Sur - IISGS, Vigo, Spain
}

Correspondence should be addressed to $\mathrm{F}$ Mallo

Email

fmallo@uvigo.es

\begin{abstract}
Diabetes mellitus exerts metabolic stress on cells and it provokes a chronic increase in the long-term activity of the hypothalamus-pituitary-adrenocortical (HPA) axis, perhaps thereby contributing to insulin resistance. GLP-1 receptor (GLP-1R) agonists are pleiotropic hormones that not only affect glycaemic and metabolic control, but they also produce many other effects including activation of the HPA axis. In fact, several of the most relevant effects of GLP-1 might involve, at least in part, the modulation of the HPA axis. Thus, the anorectic activity of GLP-1 could be mediated by increasing CRF at the hypothalamic level, while its lipolytic effects could imply a local increase in glucocorticoids and glucocorticoid receptor (GC-R) expression in adipose tissue. Indeed, the potent activation of the HPA axis by GLP-1R agonists occurs within the range of therapeutic doses and with a short latency. Interestingly, the interactions of GLP-1 with the HPA axis may underlie most of the effects of GLP-1 on food intake control, glycaemic metabolism, adipose tissue biology and the responses to stress. Moreover, such activity has been observed in animal models (mice and rats), as well as in normal humans and in type I or type II diabetic patients. Accordingly, better understanding of how GLP-1R agonists modulate the activity of the HPA axis in diabetic subjects, especially obese individuals, will be crucial to design new and more efficient therapies for these patients.
\end{abstract}
Key Words
- diabetes
- HPA axis (hypothalamus- pituitary-adrenal)
- obesity
- glucocorticoid

- GLP-1

\section{Introduction}

The stress indices in Western societies are correlated with the increasing rates of obesity and metabolic syndrome. Recent data indicate that chronic stress, associated with mild hypercortisolaemia and prolonged sympathetic nervous system (SNS) activation, favours the accumulation of visceral fat and contributes to the clinical presentation of visceral obesity, type 2 diabetes mellitus (DM2) and related cardiometabolic complications. In addition, both circulating and local levels of glucocorticoids (GCs) and GC receptors (GC-Rs) in fat are markedly altered in obese subjects (Pasquali et al. 2006). Indeed, the enzymes involved in GC synthesis are expressed distinctly in adipose tissues of obese subjects. The isoenzyme 11-beta-hydrosteroid dehydrogenase 1 (11ß-HSD1) is overexpressed in visceral fat in obese subjects, irrespective of whether the circulating GC levels are within normal ranges. The striking increase in $11 \beta$-HSD1 activity in obese patients predicts enhanced local conversion of cortisone to cortisol in adipose tissue, which produces a marked increase in intra-adipose

Published by Bioscientifica Ltd 
cortisol and may promote the accumulation of visceral adipose tissue (Paulmyer-Lacroix et al. 2002, Baudrand et al. 2010). Hyperactivity of the HPA axis is positively correlated with the metabolic syndrome, suggesting a causative role for GCs in the obese phenotype (Vegiopoulos \& Herzig 2007). Indeed, Cushing's patients are characterized by a redistribution of body fat from the periphery to central/abdominal depots, which is consistent with an involvement of the GC-GR axis in this phenotype (Shibli-Rahhal et al. 2006). GCs have a distinct impact on different fat depots, whereas GCs increase lipolysis by inducing hormone-sensitive lipase (Slavin et al. 1994); they reduce lipoprotein lipase (LPL) activity in peripheral fat depots. They also promote pre-adipocyte differentiation and pro-lipogenic activity, thereby fomenting cell hypertrophy in central fat (Vegiopoulos \& Herzig 2007). Furthermore, mice overexpressing $11 \beta$-HSD1 are characterized by adipocyte hypertrophy, which is accompanied by decreased levels of the insulin-sensitizing adipocytokine adiponectin, as well as increased local and systemic levels of tumour necrosis factor (TNF), a marker of insulin resistance (Masuzaki et al. 2001). In addition to the adipocyte hypertrophy observed in this model, GCs also promote pre-adipocyte differentiation in vitro (Gregoire et al. 1998). This mechanism has been attributed to a key role in the development of central obesity and several inhibitors of $11 \beta$-HSD1 have been tested to treat obesity, DM2 and metabolic syndrome (Wang 2011, Park et al. 2014, Morgan et al. 2014).

DM2 is associated to obesity in about $80 \%$ of cases, yet metabolic alterations have also been linked to the increased activity of the hypothalamus-pituitaryadrenocortical (HPA) axis and the effects of GCs. Thus, circulating GC levels must be measured in the diagnostic evaluation of obesity and a differential diagnosis of pseudo-Cushing excluded. The contribution of the HPA axis to metabolic syndrome and obesity is becoming clearer, and thus, it must be considered when assessing the pathophysiology of diabetes, and for metabolic control and therapy.

As a result, in this review, we resume what is currently known about the involvement of the HPA axis in obesity and diabetes, the relevance of GCs to explain insulin resistance in different tissues and organs, and how prenatal stress and GCs impose a trend towards the development of obesity and diabetes in adulthood. Finally, we consider how the agonists of the GLP-1 receptor (GLP-1R) can interfere with these processes, modulating the activity of the HPA axis, the SNS and the peripheral effects of GCs, thereby providing promising clues to improve therapeutic interventions in the forthcoming years.

\section{Hypothalamus-pituitary-adrenocortical axis in metabolism}

Glucocorticoids are major regulators of energy metabolism, playing a key role in the counter-regulatory responses and metabolic adaptations to the increased energy demand provoked by stress. In general, GCs mobilize energy substrates, such as lipids and glucose, increasing their levels in systemic circulation. In the liver, cortisol induces gluconeogenesis and it potentiates the action of other hyperglycaemic hormones on glycogenolysis (e.g. glucagon, catecholamines and growth hormone), which culminates in the release of glucose by hepatocytes (van Raalte et al. 2009). In this regard, GCs promote the expression rate of limiting enzymes of gluconeogenesis in rats, including phosphoenolpyruvate carboxykinase (PEPCK) and glucose-6-phosphatase (G6Pase: Sasaki et al. 1984, Chevalier et al. 2006, van Raalte et al. 2009). In the muscle, GCs inhibit glucose uptake and glycogen synthesis, cellular processes regulated by the insulin/IGF-1 signalling pathway (Heszele \& Price 2004, Vegiopoulos \& Herzig 2007). GCs also induce catabolism in muscle by counteracting the IGF-1/insulin/PI3-kinase/Akt signalling cascade (Vegiopoulos \& Herzig 2007). It was shown that treating rats with the GC-R agonist dexamethasone (Dex) leads to reduced insulin receptor (IR) phosphorylation in skeletal muscle (Giorgino et al. 1993), while Dex can also reduce PI3 kinase activity (Saad et al. 1993, Vegiopoulos \& Herzig 2007). The effects of cortisol on glycaemia are further enhanced by increasing the breakdown of triglycerides, which provides energy and substrates for gluconeogenesis in the liver (Quan \& Walser 1992, Bollen et al. 1998, Moore et al. 1998). In addition, GCs promote the catabolism of skeletal muscle proteins by enhancing proteolysis, diminishing amino acid transport into muscle cells, inhibiting protein synthesis and inducing myostatin expression, an intramuscular protein that negatively regulates muscle mass (Smith \& Muscat 2005). As such, GCs may directly increase endogenous glucose production in different organs and indirectly antagonize the metabolic actions of insulin (Andrews \& Walker 1999). Subclinical hypercortisolism could affect glucose metabolism in cells and the prevalence of diabetes appears to increase in function of the circulating cortisol levels (for review, see Di Dalmazi et al. 2012). In fact, studies in subclinical Cushing syndrome (SCS) reported a higher

Published by Bioscientifica Ltd. 


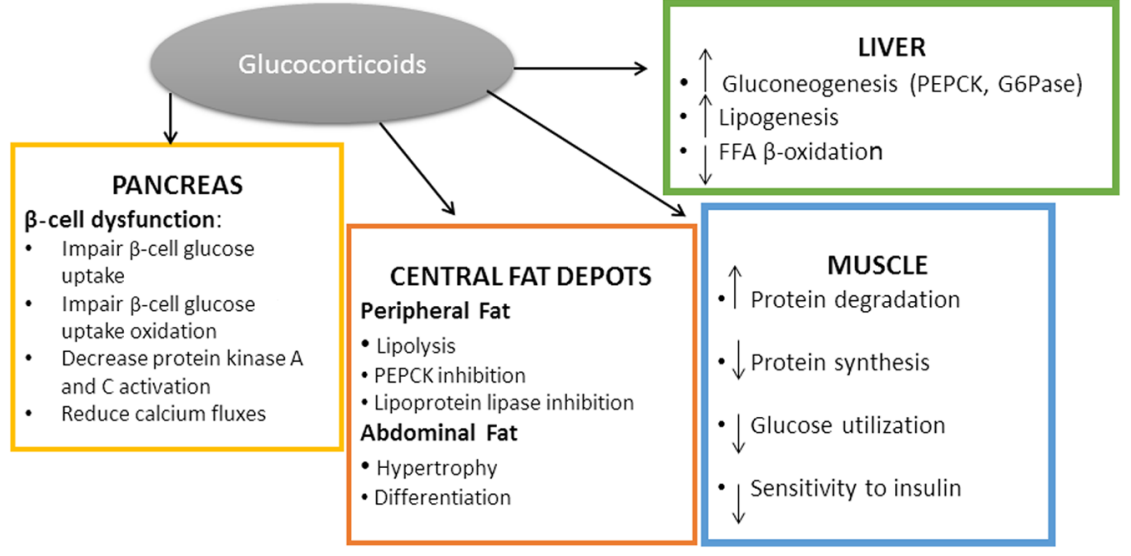

Figure 1

The actions of glucocorticoid in liver, pancreas, central fat depots and muscle. G6Pase, glucose-6-phosphatase; PEPCK, phosphoenolpyruvate carboxykinase. prevalence of diabetes mellitus in these patients, ranging from 5 to $50 \%$ (Fig. 1).

\section{HPA in diabetes}

Patients and animals with poorly controlled or uncontrolled diabetes commonly show diurnal hypersecretion of GCs and altered regulation of the HPA axis, with enhanced responses to stressors (Chan et al. 2002a,b, Sharma et al. 2014). In type 1 diabetes mellitus (DM1) patients, stressrelated adaptation of the HPA axis is impaired, with weaker adrenal overnight responsiveness to endogenous adrenocorticotropic hormone (ACTH) and lower free cortisol concentrations (Sharma et al. 2014). Such changes might initially be interpreted as an HPA adaptation that would favour glycaemic control. However, it is important to bear in mind that abrupt glycaemic changes are potent cellular stressors, as glucose is a key energy substrate for almost all cells.

HPA dysregulation in DM1 appears to involve complex interactions between the impaired sensitivity to the negative GC feedback and hypoinsulinaemia and/or hypoleptinaemia that may increase the central drive of the axis (Chan et al. 2003). Understanding the mechanisms of GC-induced glucose alterations could lead to the development of novel therapeutic strategies with reduced impact on glucose metabolism (Di Dalmazi et al. 2012).

DM2 patients have elevated basal ACTH levels (Vermes et al. 1985, Chiodini et al. 2006) and high cortisol levels, both basal and after Dex suppression (Hudson et al. 1984, Prpić-Križevac et al. 2012). In this regard, the activity of the HPA axis is enhanced in diabetic patients with asymptomatic autonomic imbalance due to prevalent parasympathetic failure. These changes may be related to the degree of neuronal dysfunction and the higher blood pressure than that observed with asymptomatic prevalent sympathetic failure or in the absence of autonomic derangement (Chiodini et al. 2006).

Insulin resistance and HPA axis Under physiological conditions, insulin triggers the fast uptake and oxidative catabolism of glucose in the liver, muscle and adipose tissue, simultaneously inhibiting glycogen lysis and gluconeogenesis in the liver during feeding (Vegiopoulos \& Herzig 2007). All the actions of insulin are mediated through the IR/IGF-1 receptor (IGF-1R), membrane-bound receptors which augment their kinase activity on ligand binding, and tyrosine phosphorylate several downstream signalling molecules, including the insulin receptor substrate 1 (IRS-1: Ferris \& Kahn 2012). Excess weight and obesity are major contributors to the development of insulin resistance and impaired glucose tolerance (Reaven 1993). Glucocorticoids induce insulin resistance by reducing the expression and phosphorylation of IRS-1 (Sakoda et al. 2000), thereby impairing the intracellular signalling activated by the IR/IGF-1R. These effects dampen the phosphatidylinositol 3-kinase (PI3-K) and protein kinase $\mathrm{B}(\mathrm{PKB}) /$ Akt activity, and markedly reduce the translocation of the glucose transporter 4 (GLUT-4) to the cellular membrane in most tissues, including skeletal muscle, adipose tissue, liver and the brain (Beaudry \& Riddell 2012). However, GCs paradoxically increase membrane GLUT-4 expression in myocardial muscle by directly activating the AMPK pathway, which enhances glycogen storage, and may provoke cardiac hypertrophy and ventricular arrhythmias. From these data, it can be inferred that increased GCs in diabetes might also contribute to higher cardiovascular risk (Wu et al. 2004, Puthanveetil et al. 2008).

Published by Bioscientifica Ltd. 
Pancreas Pancreatic $\beta$-cells account for about $70 \%$ of the total islet volume (Beaudry \& Riddell 2012), and before the development of overt DM2, the $\beta$-cell mass might change relative to whole-body adiposity and insulin resistance. Therefore, as the $\beta$-cell mass increases to compensate for greater whole-body insulin demand, the feedback system is maintained by increasing $\beta$-cell turnover through controlled mechanisms of proliferation/ neogenesis and dampened $\beta$-cell death (Topp et al. 2007). Numerous studies have shown that increased levels of free fatty acids and excessive glucose exposure (i.e. lipotoxic and glucotoxic effects) may be the main culprits in aggravating normal $\beta$-cell function (van Raalte $\&$ Diamant 2011). The elevated levels of glucose and fatty acids may decrease $\beta$-cell survival by inducing endoplasmic reticulum (ER) stress, the presence of reactive oxidative species (ROS), reduced insulin synthesis and impaired insulin signalling (Kahn 2001).

Administration of high doses of corticosterone in drinking water to mice results in a net increase in body weight, dyslipidaemia, ectopic fat deposition and hypertension, which occurs in association with insulin resistance and glucose intolerance. Both pancreatic insulin content and islet volume increase in mice exposed to corticosterone, suggesting that the increased demand for insulin brought about by insulin resistance and increased blood glucose in this model give rise to pancreatic islet $\beta$-cell compensation (Fransson et al. 2013). In this regard, GCs reduce insulin sensitivity and impair $\beta$-cell function by acting through their receptors on pancreatic $\beta$-cells (Fischer et al. 1990, Matthes et al. 1994, van Raalte et al. 2009). Studies in vitro have proven that GCs directly inhibit insulin secretion by decreasing the effectiveness of cytoplasmic $\mathrm{Ca}^{2+}$ in the secretory process (Lambillotte et al. 1997). In addition, GCs have been reported to decrease $\beta$-cell survival and proliferation (Lantz et al. 2004, Bréant et al. 2006). In this regard, treatment with GCs could downregulate the expression of the pancreatic and duodenal homeobox-1 (PDX-1) in pancreatic $\beta$-cells (Bréant et al. 2006). PDX-1 is a well-studied transcription factor critical to both $\beta$-cell development and function (Melloul 2004), favouring normal $\beta$-cell survival, the formation of new $\beta$-cells and less $\beta$-cell death (Shao et al. 2009). The reduced PDX-1 expression induced by GCs is accompanied by weaker activity of the fork-head box transcription factor (Fox)-A2 (Chen et al. 2011). Indeed, FoxA2 binds to the PDX-1 promoter and positively regulates PDX-1 gene expression (Marshak et al. 2001). PDX-1 also plays a central role in the actions of GLP-1 on insulin gene transcription and secretion. GLP-1 increases
PDX-1 transcription and in turn, PDX-1 binds to the insulin gene promoter. In addition, $\beta$-cell-specific inactivation of the PDX-1 gene in mice and dominant-negative suppression of PDX-1 in insulinoma cells are associated with the loss of GLP-1R agonist-dependent effects on pancreatic $\beta$-cells (Baggio \& Drucker 2007).

Liver One of the prominent features of liver metabolism is the de novo synthesis of glucose or gluconeogenesis during fasting, providing glucose for non-insulindependent tissues such as erythrocytes, the renal medulla and the brain (van den Berghe 1991, Vegiopoulos \& Herzig 2007). When dysregulated, gluconeogenesis contributes significantly to hyperglycaemia in DM2 patients (Consoli 1992), largely through the aberrant induction of gluconeogenic gene expression (Vegiopoulos \& Herzig 2007).

Phosphoenolpyruvate carboxykinase (PEPCK) promotes the decarboxylation of oxaloacetate to phosphoenolpyruvate. Under normal conditions, the expression of PEPCK is induced by glucagon and GCs in response to fasting, whereas a carbohydrate-rich meal and the concomitant increase in plasma insulin levels acutely decreases its rate of synthesis (Hanson \& Reshef 1997, Vegiopoulos \& Herzig 2007). G6Pase controls hepatic glucose release through glycogen lysis and its expression is disrupted by adrenalectomy (Hanson \& Reshef 1997, Barthel \& Schmoll 2003). By contrast, GC treatment of isolated hepatocytes induces G6Pase mRNA expression (Vegiopoulos \& Herzig 2007). The loss of insulin-dependent repression of PEPCK and G6Pase gene expression promotes substantial hyperglycaemia under insulin-resistant conditions (Saltiel \& Kahn 2001).

Muscle Skeletal muscle plays a crucial role in glucose metabolism, as it takes up as much as $80 \%$ of the circulating postprandial glucose (DeFronzo et al. 1981), representing the body's largest glycogen store. Notably, the uptake of glucose by skeletal muscle is insulindependent (van Raalte et al. 2009). Skeletal muscle accounts for approximately $40 \%$ of the body mass and it is a major target for GCs (Kuo et al. 2013). Metabolic regulation by GCs is most apparent in weight loss and in patients with Addison's disease (glucocorticoid hormone deficit) experiencing hypoglycaemia. Conversely, the excess GC associated with Cushing's syndrome (Smith \& Muscat 2005) is reflected by hypertension, central obesity and hyperglycaemia. Excess GC promotes insulin resistance by suppressing glucose uptake, mainly by inhibiting the translocation of the Glut-4 glucose

Published by Bioscientifica Ltd. 
transporter to the cell surface in muscle fibres (Weinstein et al. 1995, Coderre et al. 1996, Smith \& Muscat 2005, Vegiopoulos \& Herzig 2007). However, it also inhibits lipoprotein lipase (LPL) activity, subsequently reducing circulating triglyceride uptake and generating hypercholesterolaemia (Smith \& Muscat 2005). In addition, GCs enhance protein and lipid catabolism, which may in turn reduce insulin sensitivity in skeletal muscle fibres (van Raalte et al. 2009). While the involvement of GCs in the induction of insulin resistance is of great interest with respect to the pathogenesis of DM2, regulating protein metabolism is a major concern in disorders associated with severe muscle atrophy (Vegiopoulos \& Herzig 2007).

\section{Hypothalamic actions of glucocorticoids in diabetes}

An important mean of regulating the HPA axis is through the negative feedback of the GCs that inhibit pituitary secretion of ACTH, and the hypothalamic secretion of $\mathrm{CRF}$ and vasopressin. This negative feedback of GCs occurs through the activation of both mineralocorticoid receptors (MRs) and/or GC receptors (GC-Rs) located in the hypothalamus and pituitary. At the pituitary level, the activation of the GC-Rs augments the local secretion of Annexin-1, which inhibits ACTH secretion by corticotroph cells (John et al. 2007). GCs repress the proopiomelanocortin (POMC) gene in the pituitary and also the POMC, CRF and AVP genes in the hypothalamus. GC-Rs are present in the hypothalamic CRF-producing neurons (Fenoglio et al. 2004) and GCs negatively regulate CRF expression levels in these cells (Harbuz \& Lightman 1989). Although it is generally assumed that GCs repress CRF transcription by interacting with the putative negative GC response element in the proximal promoter, recent evidence suggests that such an interaction does not occur during the physiological elevation of the natural GC, corticosterone (Liu et al. 2010). The weak influence of GCs on CRF transcription, compared with the marked transcriptional repression of AVP in parvocellular neurons and pituitary POMC, suggests that GCs indirectly repress CRF transcription through the modulation of neural pathways controlling CRF neuron activity (Uchoa et al. 2014).

The short-term inhibition of ACTH secretion requires an acute rise in GCs. By contrast, the more delayed inhibitory effect on HPA activity depends on the intensity of the stimulus and the magnitude of the corticosteroid feedback, as well as on the neuroanatomical pathways that mediate the activation of the HPA axis (Keller-Wood 2015). GC feedback involves the modulation of direct and indirect circuits controlling CRF neuron activity. Most of the afferent innervation to the CRF-containing region of the PVN comes from the STN (Nucleus of the Solitary Tract, Cunningham et al. 1990); the noradrenaline-adrenaline neurons of the STN contribute to the excitation of the PVN neurons that control the responses of the HPA axis to stress (Pacak et al. 1995). Activation of the HPA axis is also mediated by non-catecholaminergic projections from the SNT, these emanating from neurons expressing GLP-1 that send projections to CRF neurons (Sarkar et al. 2003). Blocking GLP-1 receptors reduces the ACTH and corticosterone responses to acute physiological or psychogenic stressors, and local infusion of GLP-1 into the PVN provokes corticosterone release (Kinzig et al. 2003).

Altered GC negative feedback can promote excess GC production and an increased peripheral effect of this hormone, as seen in Cushing's disease. In fact, obesity and DM2 may be associated with a dysfunction of the HPA axis (Islam et al. 2012). The activity of the HPA axis is enhanced in DM2 patients, as evident by the elevated urinary-free cortisol, the diminished cortisol suppression Dex and the increased ACTH-induced cortisol levels. Abdominal obesity and the presence of chronic complications augmented the activity of the HPA axis in DM2, alterations that might be explained by the abnormal activation of the HPA by a defective hypothalamic response to GC and impaired negative feedback (Longui et al. 2003).

\section{Metabolic programming during development: glucocorticoids and incretins}

A number of studies have confirmed the association between birth weight, impaired glucose tolerance and DM2, first reported in the Hertfordshire study (Barker 1998). These studies showed that subjects with low body weight at birth have a six-fold higher risk of developing DM2 than those within the normal weight range at birth. Insulin production and tissue insulin resistance in the prenatal and early postnatal environment is not only crucial to establish the growth profile of the fetus and newborns, but also it is now considered as a key factor contributing to disease susceptibility in later adult life (Barker 1998). Thus, the way a developing fetus adapts to an insult in utero may produce permanent changes in structure, physiology and metabolism regulation. Later in life, particularly when there is a mismatch between the

Published by Bioscientifica Ltd. 
early and later life environment, these changes become maladaptive and they are associated with increased risk of glucose intolerance and DM2, as well as of cardiometabolic and psychiatric diseases. This phenomenon is termed early-life or developmental 'programming' (Barker 1998, Reynolds et al. 2013).

\section{The HPA axis in metabolic programming during development}

One of the key hormonal systems activated as part of the adaptive responses to insults is the HPA axis, which is thought to transmit the effects of maternal stress to the developing fetus. Animal studies and some limited evidence from humans suggest that adverse events in early life may deeply affect the neuroendocrine development of the fetus through the action of GCs (Holness et al. 2000). During development, GCs act at the cellular and molecular level to induce changes in tissue growth and differentiation through direct and indirect mechanisms. Glucocorticoid exposure in utero alters the expression of enzymes, receptors, ion channels and transporters in a wide range of different cell types (Erdeljan et al. 2001, Clarke et al. 2002). They also affect the expression of various growth factors, cytoarchitectonic proteins, binding proteins and components of the intracellular signalling machinery. As such, GCs influence the basic cell function and its responses to endocrine, metabolic and other stimuli, influencing proliferation and terminal differentiation (Fowden \& Forhead 2004).

Circulating levels of GCs rise dramatically during pregnancy (Jung et al. 2011) due to the increased production of corticotrophin-releasing factor (CRF) in the placenta. The fetus is protected from the high levels of maternal GCs through the corticosteroid-binding globulin, which is increased by estrogens and helps to buffer circulating free corticosteroid levels. In addition, the placental enzyme $11 \beta$-hydroxysteroid dehydrogenase type 2 (HSD2) protects the fetus (Edwards et al. 1993), preventing it from exposure to excess GC by converting active GCs (cortisol) into inactive GCs (cortisone). This placental buffering against GCs remains intact throughout pregnancy, although it may be damp-weakened by inflammation, drugs or diet, and the resulting increase in GC transfer to the fetus will lower birth weight and potentially produce adverse effects (Reynolds et al. 2013).

Maternal stress induced by undernutrition leads to lifelong changes in the fetal HPA axis (Barker 1998), and an increase in maternal and fetal corticosterone levels (Blondeau et al. 2001). In utero malnutrition leads to irreversible alterations in $\beta$-cell development, resulting in a decreased $\beta$-cell mass, while high $\beta$-cell numbers are associated with low corticosterone levels during pregnancy (Blondeau et al. 2001). In this regard, maternal food restriction to $50 \%$ of the daily intake of control rats decreases birth weight, and the pups show a $25 \%$ decrease in $\beta$-cell density, a $30 \%$ decrease in the absolute $\beta$-cell mass and around a $40 \%$ decrease in total insulin content relative to the controls (Garofano et al. 1997). This phenotype persists into adulthood, and both males and females develop gradual glucose intolerance around 4 months of age, as well as insulin resistance and DM2 at 17 months of age, with a characteristic slower onset and distinct islet morphology in females (Shahkhalili et al. 2010, Nielsen et al. 2014). In addition, corticosterone levels are elevated by $30 \%$ in fetuses from food-restricted dams, while the fetal adrenal weight, the fetal pancreatic insulin content and the $\beta$-cell mass decreases. However, preventing the increase in corticosterone in the foodrestricted dams restores the fetal $\beta$-cell mass, while reducing the exposure to GC augments the $\beta$-cell mass two-fold, increasing mean islet size and islet number (Blondeau et al. 2001). Gestational caloric restriction decreases the number of neurogenin 3 (Ngn3)-positive endocrine progenitor cells in fetal rats, partially due to the elevation in corticosterone (Gesina et al. 2006), which represses several genes important for $\beta$-cell development and function via peroxisome proliferatoractivated receptor-c coactivator $1 \mathrm{a}$ (PGC-1 $\alpha$ ) expression (Valtat et al. 2013). Accordingly, pregnant rats treated with Dex during the last week of gestation have a reduced $\beta$-cell mass and, if Dex treatment is extended for the whole pregnancy, fetal islet vascularization and $\beta$-cell proliferation are also reduced (Shen et al. 2003, Dumortier et al. 2011). Furthermore, the transcription factors implicated in $\beta$-cell differentiation, such as PDX-1, Pax6 and Nkx6.1, are downregulated by Dex administration, whereas the exocrine-specific transcription factors Ptf1-p48 and Hes1 are upregulated by exposure to GCs, suggesting that GCs impair $\beta$-cell development by modulating transcription factors as their preferential molecular targets (Gesina et al. 2004).

There is an increased risk of glucose intolerance associated with prenatal undernutrition and impaired fetal growth in humans, which become susceptible to metabolic diseases when exposed to a calorie-rich diet. Indeed, obese children with small-for-gestational-age birthweights have reduced insulin-secreting capacity (Nielsen et al. 2014). The risk of giving birth to a

Published by Bioscientifica Ltd 
macrosomic neonate increases with the body mass index in women with normal glucose tolerance (Sewell et al. 2006), and these children have an increased risk of developing DM2 (Nielsen et al. 2014). Animal studies confirm that maternal obesity may provoke nonalcoholic fatty pancreas disease in their offspring, which involves fat deposition and inflammation, resulting in pancreatic fibrosis (Cerf et al. 2005).

A high-fat diet (HFD) during gestation predisposes offspring to a metabolic syndrome-like phenotype, including glucose intolerance and increased body weight in adulthood (Srinivasan et al. 2006). Fetuses of high calorie-fed rats had elevated plasma interleukin-6, TNF $\alpha$ and chemokine ligand 2, as well as enhanced placental TNF $\alpha$ (Desai et al. 2013).

\section{Incretins and metabolic programming in development}

In animal models of intrauterine growth retardation (IUGR) induced by bilateral ligation of the uterine arteries at 19 days of gestation, diabetes develops in the adults at 15-26 weeks of age (Simmons et al. 2001). Exendin-4 (Ex-4) administration during the neonatal prediabetes period prevents the development of diabetes in this animal model, normalizing glucose tolerance and rescuing the eventual decline in the $\beta$-cell mass, as well as restoring PDX-1 expression to normal levels and avoiding the progressive reduction in $\beta$-cell mass observed in IUGR rats (Stoffers et al. 2003). Ex-4 permanently reverses epigenetic modifications of this key $\beta$-cell gene, PDX-1, as well as increases histone acetyl transferase (HAT) activity. These phenomena restore chromatin structure at the PDX-1 promoter and prevent DNA methylation, thereby preserving PDX-1 transcription (Pinney et al. 2011). In addition, Ex-4 normalizes islet vascularization in these animals (Ham et al. 2009). The vascular bed plays an important role in normal pancreatic function, producing signals for differentiation and development, and delivering of nutrients to $\beta$-cells. The vascularity of the pancreas is extremely important in determining the number of $\beta$-cells in the offspring. Following short-term neonatal exposure of IUGR rats to Ex-4, islet vascularity was promptly restored to control levels (Ham et al. 2009). Moreover, Ex-4 administration in the perinatal period prevents the development of hepatic insulin resistance in adult IUGR animals, improving mitochondrial function and reducing oxidative stress (Raab et al. 2009). Thus, the use of Ex-4 and other incretins as therapeutic agents to prevent the development of diabetes from an adverse in utero environment should be explored further.

\section{Incretins and the HPA axis}

\section{Glucagon-like peptide 1 (GLP-1) and HPA axis crosstalk}

In the rat brain, GLP-1 is synthesized by noncatecholaminergic neurons in the nucleus of the solitary tract (STN) and in the reticular nucleus of the medulla oblongata (Larsen et al. 1997). The majority of the proglucagon-expressing neurons in the STN project to the hypothalamus in a target-specific manner, predominantly restricted within the boundaries of the paraventricular nucleus (PVN) and dorsomedial hypothalamic nuclei (DMH: Tang-Christensen et al. 2000, Dakin et al. 2001, Vrang et al. 2007). By contrast, GLP-1R mRNA is expressed in all hypothalamic areas that receive GLP-1immunoreactive fibres (GLP-1-ir: Merchenthaler et al. 1999), such that GLP-1R expression is confined to the compact part of the DMH (Tang-Christensen et al. 2000).

Dual immunolabelling reveals the close apposition of numerous GLP-1-ir nerve fibres to $65 \%$ of the CRF neurons detected in the medial parvocellular subdivision of the rat PVN (Sarkar et al. 2003). Central administration of GLP-1 produces a dose-related increase in Fos-immunoreactivity in the hypothalamic PVN, the supraoptic nucleus and the arcuate nucleus (Larsen et al. 1997, Rowland et al. 1997). Accordingly, centrally administered GLP-1 activates the HPA axis, producing an increase in ACTH (Kinzig et al. 2003, Lantz et al. 2004) and arginine vasopressin (AVP: Larsen et al. 1997), as well as the circulating levels of corticosterone (Larsen et al. 1997, Kinzig et al. 2003, Lantz et al. 2004, Gil-Lozano et al. 2013). CRF has been proposed to be the principal mediator of the effects of GLP-1 in the HPA axis, since antagonism of CRF receptors by peripheral astressin injection (a non-selective CRF receptor antagonist) attenuates the GLP-1-induced elevation in plasma ACTH and corticosterone (Kinzig et al. 2003). Additionally, central administration of Ex-4 provokes a potent stimulation of $\mathrm{ACTH}$ and corticosterone, and this effect is blunted by pre-treatment with astressin, although a weak corticosterone response is still evident (Gil-Lozano et al. 2014).

Peripheral intravenous (i.v.) administration of the GLP-1 (7-36) amide to conscious, freely moving or anesthetized rats increases the circulating levels of adrenal steroids (corticosterone and aldosterone) in a time-dependent manner (Gil-Lozano et al. 2013, 2014). This marked elevation of corticosteroid levels triggered by GLP-1 is preceded by an increase in ACTH levels, and it is not surprising that the activation of the HPA axis is weaker when GLP-1 is injected intraperitoneally

Published by Bioscientifica Ltd 
(i.p., Gil-Lozano et al. 2010). Similarly, its Ex-4 analogue effectively increases the circulating GC levels when administered centrally or peripherally. This effect of Ex-4 is more potent than that of GLP-1, producing higher hormone levels that persist for longer in normal animals, as well as in diabetic rats induced by streptozotocin and MKR mice, an animal model of DM2 not associated to obesity. These effects of Ex-4 suggest that its influence in regulating the HPA axis may be as relevant as its insulinotropic activity. Interestingly, the effects of Ex-4 on the activity of the HPA axis appear to be independent of the animal's metabolic status, and indeed, it acts similarly in rats fed ad libitum and fasted rats (Gil-Lozano et al. 2010). In this regard, sub-chronic Ex-4 administration produces a number of effects that resemble chronic stress, including overactivation of the HPA axis during the trough hours, disruption of circadian GC secretion, hypertrophy of the adrenal gland, decreased adrenal gland sensitivity, impaired pituitary-adrenal stress responses, and reductions in both food intake and body weight. In addition, a three-fold increase in diuresis was observed followed by a 1.5 -fold increase in water intake, effects that were abolished by adrenalectomy (Gil-Lozano et al. 2013).

Likewise, both GLP-1 (7-36)-amide and Ex-4 augmented cortisol secretion in humans, in both healthy controls and DM1 patients (Gil-Lozano et al. 2010), which may be part of a counter-regulatory response to reductions in glycaemia due to increased insulin secretion. However, similar responses are also observed in DM1 subjects who lack insulin secretory capacity, and in whom glycaemic reduction induced by the incretin mechanism cannot occcur, neither hormonal counter-regulatory response occurs. This gives evidence that the effects of GLP-1 on the HPA axis are completely independent of its insulinotropic activity and that they are exerted by different mechanisms. The mechanism whereby circulating GLP-1 activates the HPA axis remains unclear, although the increases in ACTH after Ex-4 and GLP-1 administration suggest it involves a central mechanism. However, a direct effect on the pituitary-inducing ACTH release by corticotrophin cells can be excluded, as absence of such responses is observed in primary pituitary cell cultures (Malendowicz et al. 2003, Pérez-Tilve et al. 2010).

\section{GLP-1 and sympathetic nervous system (SNS) interplay}

The GLP-1 system can also regulate sympathetic outflow. Catecholamine neurons in the area postrema (AP) link peripheral GLP-1 and the central sites of autonomic control that mediate its diverse neuroendocrine and autonomic effects (Yamamoto et al. 2003). It has been hypothesized that neurons in the AP may be involved in rapid homeostatic responses to changes in fluid and nutrient balances, including the regulation of blood pressure (Chan \& Sawchenko 1994) and heart rate (Ferguson \& Smith 1991), food and water intake (Ritter \& Taylor 1990, Gil-Lozano et al. 2013, 2014), and the secretion of neuroendocrine hormones (Cunningham et al. 1994). Central administration of Ex-4 produces a dose-dependent increase in the mean arterial blood pressure and heart rate of unrestrained conscious rats, and it also induces the appearance of Fos in several autonomic brain nuclei and the adrenal medulla (Yamamoto et al. 2002). In fact, the effects of Ex-4 on GC secretion may be partially mediated by the sympatho-adrenal system, a hypothesis supported by the significant attenuation of the robust corticosterone response elicited by peripheral Ex-4 in bilateral adrenal enucleated rats which kept the adrenal cortex and in animals previously treated with guanethidine, a blocker of the sympathetic ganglia used as anti-hypertensive drug (Gil-Lozano et al. 2014). Furthermore, the acute hyperglycaemic effect elicited by Ex-4 when administered either peripherally (i.v.) or into the central nervous system (CNS; intracerebroventricular, i.c.v.) can be blocked by hexamethonium, guanethidine and adrenal medullectomy, indicating that this effect is mediated by activation of the SNS (Pérez-Tilve et al. 2010). Ex-4 increases urinary metanephrine and normetanephrine, stable metabolites of adrenaline and noradrenaline, reflecting the endogenous secretion of catecholamines in the rat.

Activation of the central sympathetic pathway by incretins will also stimulate the HPA axis, increasing the levels of its circulating components such as ACTH, AVP and GCs. Indeed, this also involves a direct peripheral link between the adrenal medulla and cortex (Ghosal et al. 2013), which explains the simultaneous increase in circulating catecholamines and GCs. Thus, GLP-1R agonists may activate both branches of the stress responses, the neural (sympathetic terminals) and humoral (adrenal medulla and cortex) pathways, which can work in a synergistic, complementary and coordinated manner (Ehrhart-Bornstein et al. 1998, Gil-Lozano et al. 2010, 2013, 2014).

In addition, GLP-1 also appears to play a broad role in the spectrum of responses to interoceptive stimuli, such as toxins and inflammatory mediators. The anatomical location of GLP-1-producing neurons in the STN makes them ideally suited to play a key role in coordinating the recruitment of appropriate neuronal responses to these

Published by Bioscientifica Ltd. 
interoceptive stressors. There are several reports showing that chemical stressors alike $\mathrm{LiCl}$ and lipopolysaccharide (LPS) activate GLP-1ergic neurons, and that GLP-1Rs play a major role in the neuronal responses to anorexia and conditioned taste aversion induced by $\mathrm{LiCl}$ (van Dijk et al. 1997, Thiele et al. 1998, Rinaman 1999, Seeley et al. 2000). Moreover, administration of GLP-1 (7-36) amide to the central nucleus of the amygdala increases anxiety, whereas that of the GLP-1R antagonist $\operatorname{Ex}(9-39)$ blocks the increase of stress hormones associated with the administration of $\mathrm{LiCl}$, and thus both the endocrine and anxiety responses (Kinzig et al. 2003). Accordingly, central infusion of GLP-1 also decreases the number of drinking episodes in the punished drinking test, without affecting unpunished drinking, further supporting an anxiogenic effect of central GLP-1 administration (Möller et al. 2002). Recent studies suggest that GLP-1 signalling is involved in the processing of both psychogenic and systemic stressors (Ghosal et al. 2013). Accordingly, the increase in GCs associated with stress responses promotes a rapid and transient decrease in pre-pro-glucagon mRNA in the nerve terminals of the PVN, probably due to recent neuronal activation and peptide release. Furthermore, stress-induced downregulation of GLP-1 mRNA in the PVN was blocked by adrenalectomy with basal corticosterone replacement (Zhang et al. 2010). Together, the existing data are consistent with a feedback mechanism whereby stress-induced GC secretion causes an acute and transient reduction in the CNS availability of GLP-1 (Zhang et al. 2009).

\section{GLP-1, GCs and the control of food intake}

The distribution of GLP-1 and its receptor in the brain suggests that central GLP-1 acts as a neurotransmitter/ neuromodulator in the neuroendocrine system. GLP-1 injection (i.c.v.) is a powerful inhibitor of feeding in fasted rats, whereas the specific GLP-1R antagonist, Ex(9-39), blocks the inhibitory effect of GLP-1 on food intake (Navarro et al. 1996, Tang-Christensen 1996, Turton 1996), while its chronic central administration reduces body weight (Turton 1996, van Dijk 1996). In addition, GLP-1 (i.c.v.) acutely inhibits water intake, concomitant with an increase in urine output due to the accompanying natriuresis (Tang-Christensen 1996, Gil-Lozano et al. 2013). The diuretic effects of liraglutide (LIR), a long-lasting GLP-1R agonist, are abolished in adrenal medullectomized rats (surgical ablation of the adrenal medulla), indicating that some relevant effects of incretins on the control of the hydro-electrolyte equilibrium may be mediated by the adrenal medulla and the SNS (Gil-Lozano et al. 2014).

Chronic daily peripheral administration of Ex-4 (12 days) produces a progressive increase in the ingestion of non-nutritive substances (pica) coupled with stable, sustained food intake and body weight suppression. By contrast, daily LIR administration reduces the pica response and food intake, but in a more transient manner (Kanoski et al. 2012a). Furthermore, the nausea response accompanying peripheral Ex-4 administration occurs via a vagal-independent pathway involving GLP-1R activation in the brain. Indeed, the Ex-4-induced pica response is attenuated by co-administration (i.c.v.) of $\operatorname{Ex}(9-39)$, but not by vagotomy (Kanoski et al. 2012a).

GLP-1 also elicits a potent aversive effect in rodents, including the development of conditioned taste aversion (CTA: Thiele 1997), which may contribute to the anorectic actions of this peptide. In fact, GLP-1 can modulate the activity of key mesolimbic areas involved in reward to food and drugs such as alcohol, amphetamine or cocaine (Dickson et al. 2012, van Bloemendaal et al. 2014). From this perspective, GLP-1 affects multiple tasks controlling food intake, including hunger-driven behaviour, the hedonic value of food and food motivation, and it modulates the hypothalamic food-related neuroendocrine circuits (Skibicka 2013). Furthermore, the hypothalamic circuits involved in food control are deeply influenced by afferents coming from the STN (sympathetic control), sensory peripheral afferents (taste, gut motility and fullness, pain, etc.), and those from the reward and motivational areas, most of which express the GLP-1R that is activated to promote the responses described (Richard et al. 2014, 2015). Like GLP-1, the endogenous brain CRF system is also involved in appetite regulation (Heinrichs \& Richard 1999), and specifically, the CRF stress system and its activation of the HPA axis may drive the consumption of energy-dense palatable foods, as well as relieving the negative emotional state that hinders this type of food consumption (Cottone et al. 2009).

Most pharmacological data concerning the regulation of energy balance by the CRF system have been obtained through acute CRF and urocortin (Ucn) administration, which inhibits food intake in a dose-dependent manner (Arase et al. 1988). However, while the effect of central CRF administration on feeding behaviour is rather short lasting for 1-6h, the effect of central Ucn administration persists for 12-24h (Contarino et al. 1999). Furthermore, chronic infusion of Ucn into the arcuate-ventromedial region causes anorexia, suggesting that both the ventromedial hypothalamic nucleus (VMH), which expresses the CRF2

Published by Bioscientifica Ltd 


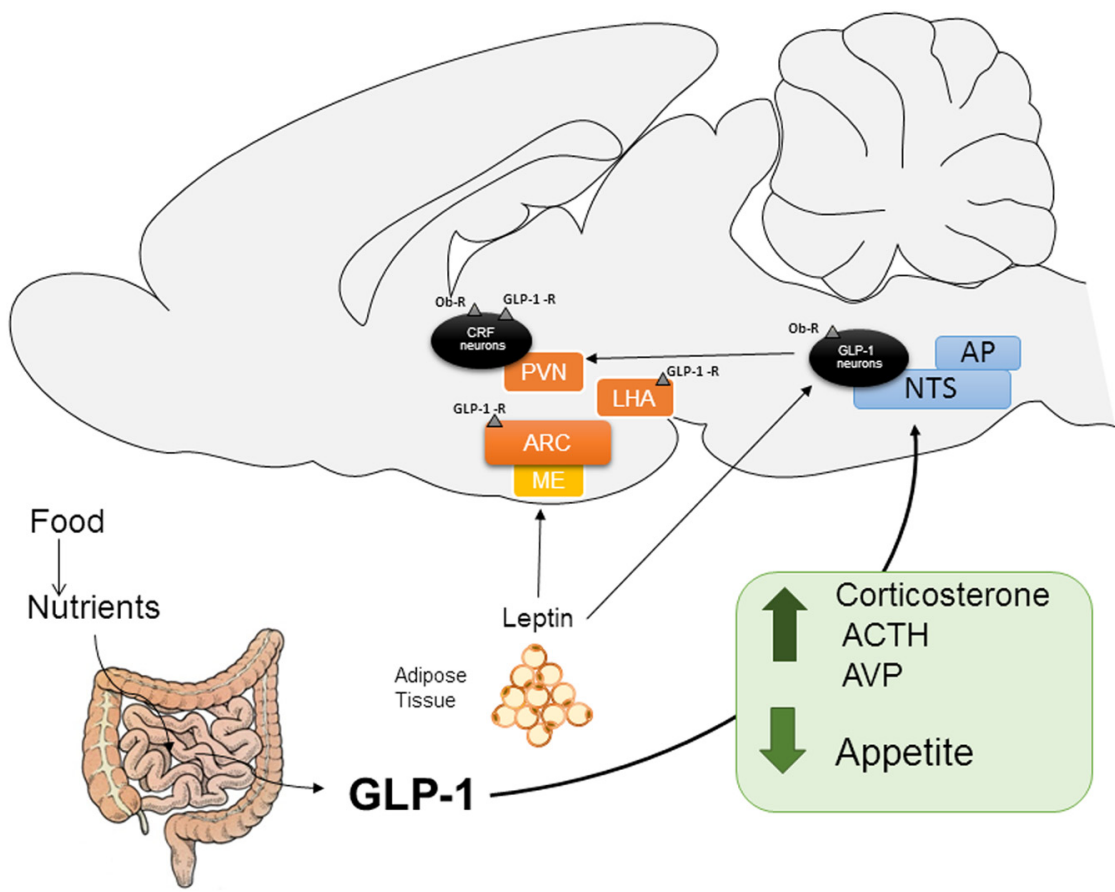

Figure 2

The anorexigenic actions of GLP-1 and CRF in the hypothalamus might be affected by leptin. Endogenous leptin receptor b (ObRb) signalling in the medial solitary tract nucleus (STN) is required for the normal control of food intake and body weight and for meal size regulation through the processing of physiological satiation signals. ACTH, adrenocorticotrophic hormone; $A P$, area postrema; $A R C$, arcuate nucleus; AVP, vasopressin; $C R F$, corticotrophin-releasing factor; LHA, lateral hypothalamic area; ME, median eminence; PVN, paraventricular nucleus. receptor, and the arcuate nucleus, which expresses the CRF1 receptor, may be the site mediating the anorexic effects of CRF-related peptides (Heinrichs \& Richard 1999). Moreover, CRF mediates the anorexic effects of GLP-1 in chicks, although the sensitivity of this response depends on the chick strain (Tachibana et al. 2006). Furthermore, central CRF mediates the inhibition of gastric emptying induced by GLP-1 in the rat (Nakade et al. 2006). Thus, there is increasing evidence that the anorectic effects of GLP-1 are mediated by CRF and probably by the activation of the HPA axis.

The anorexigenic actions of GLP-1 and CRF in the hypothalamus might be affected by leptin. Signalling through the endogenous leptin receptor (LepRb) in the medial STN is required for the normal control of food intake and body weight, and to regulate meal size by processing of physiological satiation signals (Kanoski et al. 2012a,b). Intraperitoneal leptin administration augments the hypothalamic GLP-1 in food-restricted mice (Goldstone et al. 2000). Furthermore, the long isoform of the leptin receptor (OB-Rb) was localized in GLP-1 neurons originating in the STN, and i.c.v. injection of Ex (9-39) at the onset of the dark phase blocks the reduction of food intake and body weight of leptin pretreated rats (Goldstone et al. 1997). In addition, i.c.v. injections of leptin during a 40-h fasting significantly increase the CRF mRNA expression in the PVN (Schwartz et al. 1996). Moreover, the suppression of nocturnal food intake induced by i.c.v. leptin injection is substantially attenuated in rats previously administered an i.c.v. injection of an anti-CRF antibody (Okamoto et al. 2001). In this regard, pre-treatment with $\operatorname{Ex}(9-39)$ attenuates the leptin-induced increase in CRF in the hypothalamus (Fig. 2, Gotoh et al. 2005).

\section{GLP-1 and GC crosstalk in adipose tissue}

Physiological regulation of lipid inflow/outflow in adipose tissue is under the control of two main factors: catecholamines-promoting lipolysis and insulinpromoting lipogenesis (Fig. 3). In function of the overall body energy expenditure and the availability of metabolic substrates, inflow or outflow of lipid from adipose tissue predominate. In addition to these major factors, GCs have strongly influenced the control of lipid storage, as they are lipolytic, and increased the circulating free fatty acids. In fact, a key enzyme in the lipolytic cascade is the hormone-sensitive lipase, the expression of which is directly dependent on GCs. Thus, increasing GC levels should favour the lipolytic balance in adipose tissue. GCs are more predominant in obese subjects, as well as in diabetics (see above), yet the lipolytic effect of GCs in the latter is paradoxically demised or completely lost, or at least masked by the potent lipogenic actions of insulin, especially in DM2 obese subjects with hyperinsulinism (Peckett et al. 2011, Prentki \& Madiraju 2012). 


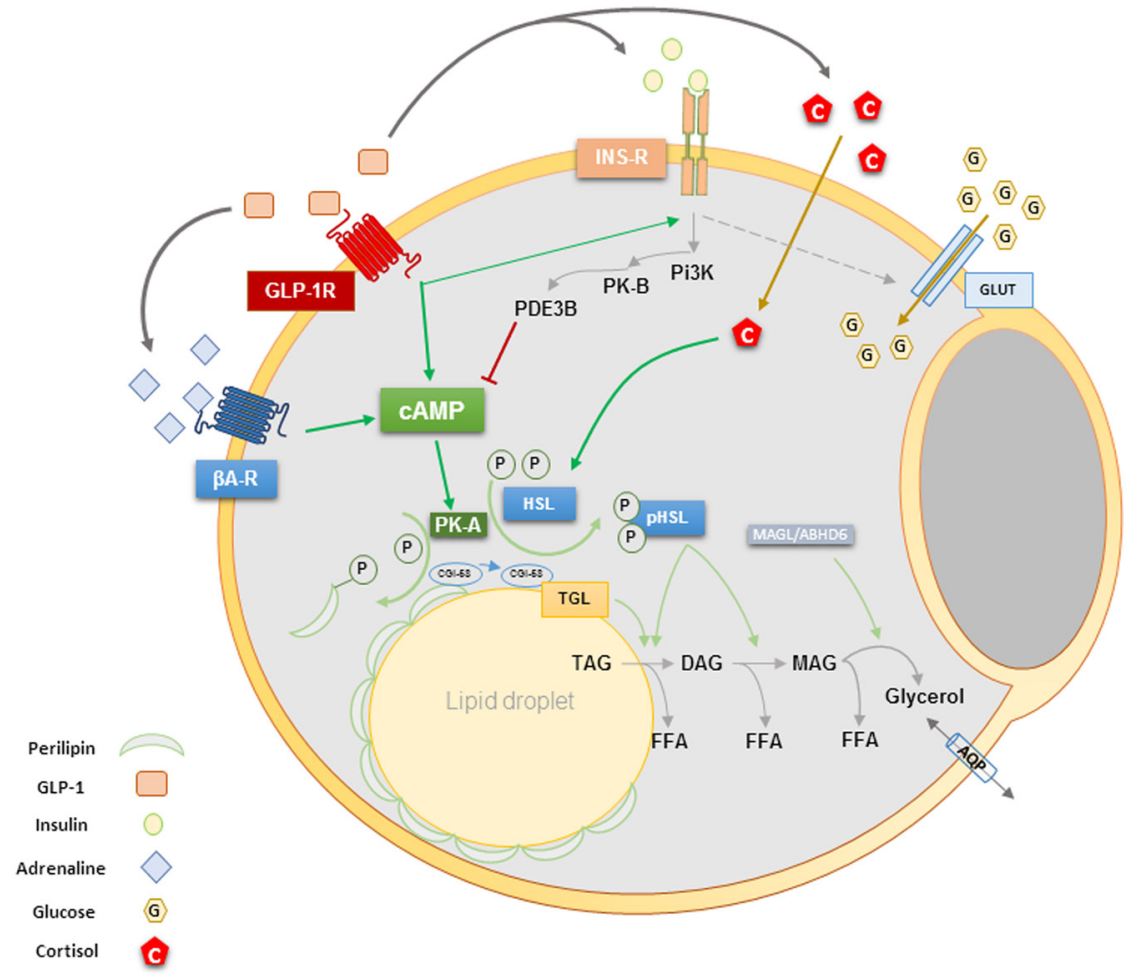

Figure 3

Lipolysis is controlled by two major mechanisms. On one hand: activation of $\beta$-adrenergic receptors increases intracellular cAMP that activates protein kinase A (PKA). PKA phosphorylates perilipin allowing the cleavage of triglycerides (TGLs) at lipid droplet, although PKA also phosphorylates hormonesensitive lipase (HSL) that becomes active for releasing free fatty acids (FFA) from triacylglycerol (TAG) and diacylglycerol (DAG). On the other hand, the activation of insulin receptor (INS-R) increases phosphodiesterase 3B (PDE3B), which blocks the production of cAMP and thereby prevents lipolysis, while also increasing membrane glucose transport that will contribute to fat deposition (Peckett et al. 2011, Prentki \& Madiraju 2012). GLP-1 modulates all factors that intervene in this process. The activation of the GLP-1R also increases CAMP potentiating the activities of the $\beta$-adrenergic receptor. It also enhances insulin sensitivity in adipose and membrane glucose transport. HSL expression is dependent on glucocorticoids, since they have potent lipolytic actions. In addition, GLP-1 also participates indirectly in the control of the whole lypo-modulatory system by increasing the circulating and local levels of insulin, catecholamines and corticoids. The resultant effect may be different in changing physiological or pathophysiological conditions, but it appears that the lipolytic actions of GLP-1 are predominant. AQP, aquaporin; CGI-58, comparative gene identification-58; MAG, monoacylglycerol; MAGL/ABHD6, monoacylglycerol lipase/ $\alpha / \beta$-hydrolase domain containing 6 .

GLP-1 has a significant influence on adipocyte biology and GLP-1R agonists provoke a dose-dependent increase in the release of glycerol from human adipocytes in primary culture. This is true of the native GLP-1 (7-36) amide and Ex-4, revealing an imbalance in lipolysis (Sancho et al. 2006, Barbarroja et al. 2012). The GLP-1R is differentially expressed in human fat from distinct locations; moreover, this GLP-1R expression correlates well with the insulin resistance of visceral and subcutaneous fat (Barbarroja et al. 2012). Interestingly, activation of the GLP-1R can interfere with the major intracellular signalling pathways involved in the lipolytic/lipogenic balance in adipocytes. Hence, GLP-1R agonists can directly increase the uptake of glucose by cells and thereby enhance their insulin sensitivity. In addition, GLP-1R activation increases intracellular cAMP levels, which should add to the lipolytic effect of catecholamines that act in the same pathway.
Indeed, GLP-1 augments the circulating catecholamines (Boissard et al. 1996).

\section{General overview: the role of GLP-1 in the homeostatic control of metabolism}

There is solid evidence that GLP-1 activates the HPA axis through a reciprocal interaction. GLP-1 is mainly secreted after meals and it has a very short half-live in peripheral circulation (1-2 min). However, it has very different and potent effects, increasing insulin secretion, reducing glucagon and activating the HPA axis and the SNS. All these actions have anorectic effects, and they contribute in different ways and through different mechanisms to produce satiety after meals and possibly, to avoid addictive behaviours related to food, especially to very tasty food.

Published by Bioscientifica Ltd. 
The post-prandial elevation of GCs may counteract the adipogenic action of insulin and activation of the SNS is a key effector for the increased post-prandial thermogenesis (Menacho-Márquez et al. 2013), commonly speculated to be dampened in obese subjects (Fig. 4).

Although at first it may be conceived as contradictory, the capacity of GLP-1 to simultaneously induce peripheral insulin secretion and to activate the central HPA and sympathetic responses are in fact complementary mechanisms aimed at establishing a homeostatic equilibrium in normal subjects. This is also probably the main reason why the agonists of the GLP-1R never

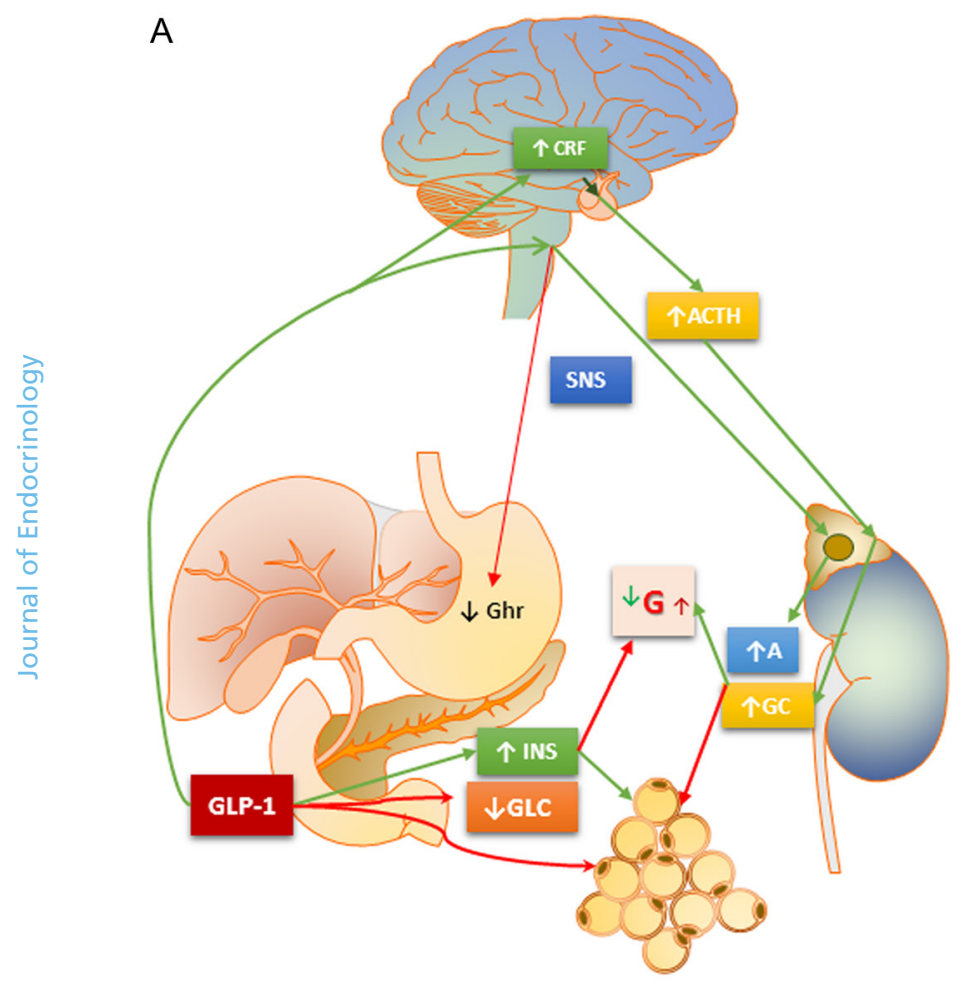

In physiological conditions promote hypoglycaemia. The ideal evolutionary design for an endogenous molecule that links food intake and metabolism by stimulating insulin secretion should include physiological homeostatic control of metabolism as an essential element in the capacity to avoid postprandial hypoglycaemia. That is what GLP-1 does very efficiently by activating the metabolic inertial brakes of counter-regulatory systems, enabling energy resources to be captured by insulin-dependent cells with no risk of suffering hypoglycaemia.

What occurs in diabetic or obese subjects is more controversial. In obese diabetic subjects,

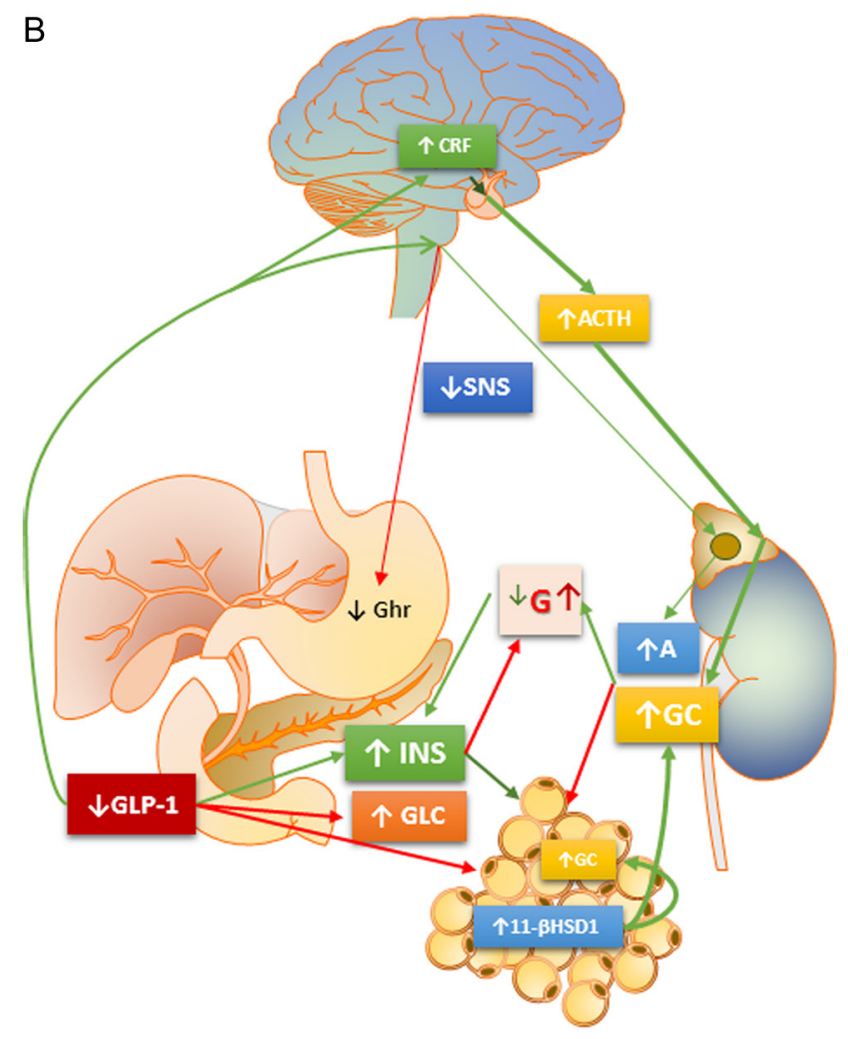

In obesity \& DM-2

\section{Figure 4}

(A) GLP-1 acts at multiple levels to control the energy metabolism. It increases insulin and reduces glucagon secretion at the pancreas, promoting energy fluxes in the sense of anabolism. At same time, GLP-1 augments CRF release and promotes the activation of the HPA axis as well as the sympathetic nervous system. Both these actions resulting in increased levels of glucocorticoids and catecholamines in circulation may contribute to avoid an excessive activity of insulin and thereby prevent hypoglycaemia. In addition, ghrelin levels became reduced, which also has a mild anabolic effect. Through all these mechanisms, GLP-1 may contribute to postprandial satiation. (B) In type II diabetes, there is a reduction in GLP-1 levels and secretion, despite of characteristic hyperinsulinism and hyperglucagonism. In addition, increased activity of the sympathetic nervous system and the HPA neuroendocrine axis has been described. Increased expression of 11- $\beta$ HSD1 in adipose tissue is also commonly present, elevating local levels of glucocorticoids. It is not clear whether the increase in glucocorticoids and catecholamines might contribute to hyperglycaemia and hyperinsulinism, but, on the contrary, the increase in HPA and SNS activity may be a direct consequence of what is interpreted by the whole system as a metabolic very stressing condition for cells: the reduced capacity to use glucose linked to insulin resistance. The administration of exogenous GLP-1R agonists may work at different levels to balance the energy metabolism, increasing insulin secretion and reducing glucagon when needed at post-prandial, later increasing cell sensitivity to insulin and activating counter-regulatory HPA and SNS to prevent insulin excessive action. A, adrenaline; ACTH, adrenocorticotrophic hormone; CRF, corticotrophin-releasing factor; G, glucose; GC, glucocorticoids; Ghr, ghrelin; GLC, glucagon; INS, insulin; SNS, sympathetic nervous system; $11-\beta$ HSD 1, 11 $\beta$-hydroxysteroid dehydrogenase-1. 
hyperinsulinaemia is part of the pathogenic mechanism, but it coexists with an increase in GCs at the tissue level. This increase is not always reflected by the circulating GC concentrations, but it is considered a key factor in peripheral insulin resistance, especially in the adipose tissue. However, it should be noted that stronger activity in the HPA axis might easily be a physiological reaction to hyperinsulinism. In that context, GLP-1 seems to have many relevant actions that tend to revert metabolism to a more balanced homeostatic state, first by transiently increasing insulin and later by reducing the need for insulin. This latter effect is achieved by ameliorating cell responses to insulin and helping to reach equilibrium in the HPA and sympathetic responses, counter-regulatory systems preventing any excessive effects of insulin.

\section{Conclusions and future directions}

In the short term, GLP-1R agonists quite effectively activate the HPA axis and provoke an increase in CRF in the hypothalamus, which promotes ACTH secretion by the pituitary. As a result, the adrenal cortex is stimulated, and the GCs and mineralocorticoids in circulation augment, with a concomitant activation of the SNS and the adrenal medulla that promotes catecholamine secretion. Thus, GLP-1R agonists activate the circuits involved in the acute neuroendocrine responses to stress. Diabetes mellitus is a stressful metabolic situation for cells, which induces chronic activation of the HPA axis in the long term, perhaps contributing to insulin resistance. This capacity of GLP-1R agonists to activate the HPA axis appears to wane over a relatively short period in humans (e.g. a week), with no relevant functional consequences in the long term (Pérez-Tilve et al. 2010).

Thus, the role of GLP-1R agonists in the physiological control of the HPA axis is far for completely understood. Future studies should address whether post-prandial GLP-1 secretion affects GC levels under physiological conditions, and it is of much interest to determine whether the satiety activities attributed to GLP-1 are mediated, at least in part, by activation of the HPA axis. Some of the most relevant interference between GLP-1R agonists and GCs at the cellular level are likely to occur in the adipose tissue, where GCs have a lipolytic effect in normal but not in obese subjects, justifying new cuttingedge therapies using $11 \beta$-HSD1 blockers. Interestingly, GLP-1R agonists also have general lipolytic effects in white adipose tissue, acting directly on adipocytes, but also indirectly activating the SNS effector. Since, GLP-1R agonists might help restore metabolic control in diabetic patients, not just by reducing food intake but also by maintaining relative high lipolytic activity in adipose tissue, these effects may perhaps be partially mediated by central CRF.

\section{Declaration of interest}

The authors declare that there is no conflict of interest that could be perceived as prejudicing the impartiality of this review.

\section{Funding}

This work was supported by the BIOCAPS project (7th EU Framework. Ref. FP7-REGPOT-2012-2013-1-316265). Yolanda Diz-Chaves has received salary grants from the Xunta de Galicia by the project INBIOMED (ref: XUGA 2012/273).

\section{References}

Andrews RC \& Walker BR 1999 Glucocorticoids and insulin resistance: old hormones, new targets. Clinical Science 96 513-523. (doi:10.1042/ cs0960513)

Arase K, York DA, Shimizu H, Shargill N \& Bray GA 1988 Effects of corticotropin-releasing factor on food intake and brown adipose tissue thermogenesis in rats. American Journal of Physiology. Endocrinology and Metabolism 255 E255-E259.

Baggio LL \& Drucker DJ 2007 Biology of incretins: GLP-1 and GIP. Gastroenterology 132 2131-2157. (doi:10.1053/j.gastro.2007.03.054)

Barbarroja N, Lopez-Pedrera C, Garrido-Sanchez L, Mayas MD, Oliva-Olivera W, Bernal-Lopez MR, El Bekay R \& Tinahones FJ 2012 Progression from high insulin resistance to type 2 diabetes does not entail additional visceral adipose tissue inflammation. PLOS ONE 7 e48155. (doi:10.1371/journal.pone.0048155)

Barker DJ 1998 In utero programming of chronic disease. Clinical Science 95 115-128. (doi:10.1042/cs0950115)

Barthel A \& Schmoll D 2003 Novel concepts in insulin regulation of hepatic gluconeogenesis. American Journal of Physiology. Endocrinology and Metabolism 285 E685-E692. (doi:10.1152/ajpendo.00253.2003)

Baudrand R, Carvajal C, Riquelme A, Morales M, Solis N, Pizarro M, Escalona A, Boza C, Pérez G, Domínguez A, et al. 2010 Overexpression of 11 $\beta$-hydroxysteroid dehydrogenase type 1 in hepatic and visceral adipose tissue is associated with metabolic disorders in morbidly obese patients. Obesity Surgery 20 77-83. (doi:10.1007/s11695-009-9937-0)

Beaudry JL \& Riddell MC 2012 Effects of glucocorticoids and exercise on pancreatic $\beta$-cell function and diabetes development. Diabetes/ Metabolism Research and Reviews 28 560-573. (doi:10.1002/dmrr.2310)

Blondeau B, Lesage J, Czernichow P, Dupouy JP \& Bréant B 2001 Glucocorticoids impair fetal beta-cell development in rats. American Journal of Physiology. Endocrinology and Metabolism 281 E592-E599.

Boissard C, Marie JC, Phan HH, Chastre E \& Rosselin G 1996 Effect of PACAP, VIP, Glucagon, and GLP1 on cAMP production and insulin release of HIT-T15 Cells is passage dependent. Annals of the New York Academy of Sciences 805 634-639. (doi:10.1111/j.1749-6632.1996. tb17533.x)

Bollen M, Keppens S \& Stalmans W 1998 Specific features of glycogen metabolism in the liver. Biochemical Journal 336 19-31. (doi:10.1042/ bj3360019)

Bréant B, Gesina E \& Blondeau B 2006 Nutrition, glucocorticoids and pancreas development. Hormone Research in Paediatrics $\mathbf{6 5}$ (Supplement 3) 98-104. (doi:10.1159/000091513)
○ 2016 Society for Endocrinology Printed in Great Britain 
Cerf ME, Williams K, Nkomo XI, Muller CJ, Dy Toit CF, Louw J \& Wolfe-Coote SA 2005 Islet cell response in the neonatal rat after exposure to a high-fat diet during pregnancy. American Journal of Physiology. Regulatory, Integrative and Comparative Physiology $\mathbf{2 8 8}$ R1122-R1128. (doi:10.1152/ajpregu.00335.2004)

Chan RKW \& Sawchenko PE 1994 Spatially and temporally differentiated patterns of c-fos expression in brainstem catecholaminergic cell groups induced by cardiovascular challenges in the rat. Journal of Comparative Neurology 348 433-460. (doi:10.1002/cne.903480309)

Chan O, Chan S, Inouye K, Shum K, Matthews SG \& Vranic M $2002 a$ Diabetes impairs hypothalamo-pituitary-adrenal (HPA) responses to hypoglycemia, and insulin responses. Diabetes 51 1681-1689. (doi:10.2337/diabetes.51.6.1681)

Chan O, Inouye K, Vranic M \& Matthews SG 2002b Hyperactivation of the hypothalamo-pituitary-adrenocortical axis in streptozotocindiabetes is associated with reduced stress responsiveness and decreased pituitary and adrenal sensitivity. Endocrinology 143 1761-1768. (doi:10.1210/endo.143.5.8809)

Chan O, Inouye K, Ridell MC, Vranic M \& Matthews S 2003 Diabetes and the hypothalamo-pituitary-adrenal (HPA) axis. Minerva Endocrinologica 28 87-102. (doi:10.1007/s00125-006-0449-3)

Chen F, Zhu Y, Tang X, Sun Y, Jia W, Sun Y \& Han X 2011 Dynamic regulation of PDX-1 and FoxO1 expression by FoxA2 in dexamethasone-induced pancreatic $\beta$-cells dysfunction. Endocrinology 152 1779-1788. (doi:10.1210/en.2010-1048)

Chevalier S, Burgess SC, Malloy CR, Gougeon R, Marliss EB \& Morais JA 2006 The greater contribution of gluconeogenesis to glucose production in obesity is related to increased whole-body protein catabolism. Diabetes 55 675-681. (doi:10.2337/diabetes.55.03.06. db05-1117)

Chiodini I, Di Lembo S, Morelli V, Epaminonda P, Coletti F, Masserini B, Scillitani A, Arosio M \& Adda G 2006 Hypothalamic-pituitary-adrenal activity in type 2 diabetes mellitus: role of autonomic imbalance. Metabolism: Clinical and Experimental 55 1135-1140. (doi:10.1016/ j.metabol.2006.04.010)

Clarke KA, Ward JW, Forhead AJ, Giussani DA \& Fowden AL 2002 Regulation of 11 beta-hydroxysteroid dehydrogenase type 2 activity in ovine placenta by fetal cortisol. Journal of Endocrinology $\mathbf{1 7 2}$ 527-534. (doi:10.1677/joe.0.1720527)

Coderre L, Vallega GA, Pilch PF \& Chipkin SR 1996 In vivo effects of dexamethasone and sucrose on glucose transport (GLUT-4) protein tissue distribution. American Journal of Physiology. Endocrinology and Metabolism 271 E643-E648.

Consoli A 1992 Role of liver in pathophysiology of NIDDM. Diabetes Care 15 430-441. (doi:10.2337/diacare.15.3.430)

Contarino A, Heinrichs SC \& Gold LH 1999 Understanding corticotropin releasing factor neurobiology: contributions from mutant mice. Neuropeptides 33 1-12. (doi:10.1054/npep.1999.0001)

Cottone P, Sabino V, Roberto M, Bajo M, Pockros L, Frihauf JB, Fekete EM, Steardo L, Rice KC, Grigoriadis DE, et al. 2009 CRF system recruitment mediates dark side of compulsive eating. PNAS 106 20016-20020. (doi:10.1073/pnas.0908789106)

Cunningham ET, Bohn MC \& Sawchenko PE 1990 Organization of adrenergic inputs to the paraventricular and supraoptic nuclei of the hypothalamus in the rat. Journal of Comparative Neurology 292 651-667. (doi:10.1002/cne.902920413)

Cunningham ET, Miselis RR \& Sawchenko PE 1994 The relationship of efferent projections from the area postrema to vagal motor and brain stem catecholamine-containing cell groups: an axonal transport and immunohistochemical study in the rat. Neuroscience 58 635-648. (doi:10.1016/0306-4522(94)90087-6)

Dakin CL, Gunn I, Small CJ, Edwards CMB, Hay DL, Smith DM, Ghatei M \& Bloom SR 2001 Oxyntomodulin inhibits food intake in the rat. Endocrinology 142 4244-4250. (doi:10.1210/en.142.10.4244)

DeFronzo RA, Jacot E, Jequier E, Maeder E, Wahren J \& Felber JP 1981 The effect of insulin on the disposal of intravenous glucose: results from indirect calorimetry and hepatic and femoral venous catheterization. Diabetes 30 1000-1007. (doi:10.2337/ diab.30.12.1000)

Desai N, Roman A, Rochelson B, Gupta M, Xue X, Chatterjee PK, Tam Tam H \& Metz CN 2013 Maternal metformin treatment decreases fetal inflammation in a rat model of obesity and metabolic syndrome. American Journal of Obstetrics and Gynecology 209 136.e1-136.e9. (doi:10.1016/j.ajog.2013.05.001)

Di Dalmazi G, Pagotto U, Pasquali R \& Vicennati V 2012 Glucocorticoids and type 2 diabetes: from physiology to pathology. Journal of Nutrition and Metabolism 2012 1-9. (doi:10.1155/2012/525093)

Dickson SL, Shirazi RH, Hansson C, Bergquist F, Nissbrandt H \& Skibicka KP 2012 The glucagon-like peptide 1 (GLP-1) analogue, exendin-4, decreases the rewarding value of food: a new role for mesolimbic GLP-1 receptors. Journal of Neuroscience $324812-4820$. (doi:10.1523/JNEUROSCI.6326-11.2012)

Dumortier O, Theys N, Ahn M-T, Remacle C \& Reusens B 2011 Impairment of rat fetal beta-cell development by maternal exposure to dexamethasone during different time-windows. PLOS ONE 6 e25576. (doi:10.1371/journal.pone.0025576)

Edwards CR, Benediktsson R, Lindsay R \& Seckl J 1993 Dysfunction of placental glucocorticoid barrier: link between fetal environment and adult hypertension? Lancet 341 355-357. (doi:10.1016/ 0140-6736(93)90148-A)

Ehrhart-Bornstein M, Hinson JP, Bornstein SR, Scherbaum WA \& Vinson GP 1998 Intraadrenal interactions in the regulation of adrenocortical steroidogenesis. Endocrine Reviews 19 101-143. (doi:10.1210/edrv.19.2.0326)

Erdeljan P, MacDonald J \& Matthews S 2001 Glucocorticoids and serotonin alter glucocorticoid receptor (GR) but not mineralocorticoid receptor (MR) mRNA levels in fetal mouse hippocampal neurons, in vitro. Brain Research 896 130-136. (doi:10.1016/S00068993(01)02075-3)

Fenoglio KA, Brunson KL, Avishai-Eliner S, Chen Y \& Baram TZ 2004 Region specific onset of handling-induced changes in corticotropinreleasing factor and glucocorticoid receptor expression. Endocrinology 145 2702-2706. (doi:10.1210/en.2004-0111)

Ferguson AV \& Smith P 1991 Autonomic mechanisms underlying area postrema stimulation-induced cardiovascular responses in rats. American Journal of Physiology. Regulatory, Integrative and Comparative Physiology 261 R1-R8.

Ferris HA \& Kahn CR 2012 New mechanisms of glucocorticoid-induced insulin resistance: make no bones about it. Journal of Clinical Investigation 122 3854-3857. (doi:10.1172/JCI66180)

Fischer B, Rausch U, Wollny P, Westphal H, Seitz J \& Aumüller G 1990 Immunohistochemical localization of the glucocorticoid receptor in pancreatic beta-cells of the rat. Endocrinology 126 2635-2641. (doi:10.1210/endo-126-5-2635)

Fowden AL \& Forhead AJ 2004 Endocrine mechanisms of intrauterine programming. Reproduction 127 515-526. (doi:10.1530/ rep.1.00033)

Fransson L, Franzén S, Rosengren V, Wolbert P, Sjöholm Å \& Ortsäter H $2013 \beta$-cell adaptation in a mouse model of glucocorticoid-induced metabolic syndrome. Journal of Endocrinology 219 231-241. (doi:10.1530/JOE-13-0189)

Garofano A, Czernichow P \& Breant B 1997 In utero undernutrition rat beta-cell development. Diabetologia 40 1231-1234. (doi:10.1007/ s001250050812)

Gesina E, Tronche F, Herrera P, Duchene B, Tales W, Czernicliow P $\&$ Breant B 2004 Dissecting the role of glucocorticoids on pancreas development. Diabetes 53 2322-2329. (doi:10.2337/ diabetes.53.9.2322)

Gesina E, Blondeau B, Milet A, Le Nin I, Duchene B, Czernichow P, Scharfmann R, Tronche F \& Breant B 2006 Glucocorticoid signalling affects pancreatic development through both direct and indirect effects. Diabetes 49 2939-2947. (doi:10.1007/s00125-006-0449-3) 
Ghosal S, Myers B \& Herman JP 2013 Role of central glucagon-like peptide-1 in stress regulation. Physiology and Behavior 122 201-207. (doi:10.1016/j.physbeh.2013.04.003)

Gil-Lozano M, Pérez-Tilve D, Alvarez-Crespo M, Martís A, Fernandez AM, Catalina PA, Gonzalez-Matias LC \& Mallo F 2010 GLP-1(7-36)-amide and exendin-4 stimulate the HPA axis in rodents and humans. Endocrinology 151 2629-2640. (doi:10.1210/en.2009-0915)

Gil-Lozano M, Romaní-Pérez M, Outeiriño-Iglesias V, Vigo E, Brubaker PL, González-Matías LC \& Mallo F 2013 Effects of prolonged exendin-4 administration on hypothalamic-pituitary-adrenal axis activity and water balance. American Journal of Physiology. Endocrinology and Metabolism 304 E1105-E1117. (doi:10.1152/ajpendo.00529.2012)

Gil-Lozano M, Romaní-Pérez M, Outeiriño-Iglesias V, Vigo E, González-Matías LC, Brubaker PL \& Mallo F 2014 Corticotropinreleasing hormone and the sympathoadrenal system are major mediators in the effects of peripherally administered exendin- 4 on the hypothalamic-pituitary-adrenal axis of male rats. Endocrinology 155 2511-2523. (doi:10.1210/en.2013-1718)

Giorgino F, Almahfouz A, Goodyear LJ \& Smith RJ 1993 Glucocorticoid regulation of insulin receptor and substrate IRS-1 tyrosine phosphorylation in rat skeletal muscle in vivo. Journal of Clinical Investigation 91 2020-2030. (doi:10.1172/JCI116424)

Goldstone AP, Mercer JG, Gunn I, Moar KM, Edwards CMB, Rossi M, Howard JK, Rasheed S, Turton MD, Small C, et al. 1997 Leptin interacts with glucagon-like peptide-1 neurons to reduce food intake and body weight in rodents. FEBS Letters 415 134-138. (doi:10.1016/S0014-5793(97)01103-4)

Goldstone AP, Morgan I, Mercer JG, Morgan DG, Moar KM, Ghatei MA \& Bloom SR 2000 Effect of leptin on hypothalamic GLP-1 peptide and brain-stem pre-proglucagon mRNA. Biochemical and Biophysical Research Communications 269 331-335. (doi:10.1006/bbrc.2000.2288)

Gotoh K, Fukagawa K, Fukagawa T, Noguchi H, Kakuma T, Sakata T \& Yoshimatsu H 2005 Glucagon-like peptide-1, corticotropin-releasing hormone, and hypothalamic neuronal histamine interact in the leptin-signalling pathway to regulate feeding behaviour. FASEB Journal 19 1131-1133. (doi:10.1096/fj.04-2384fje)

Gregoire FM, Smas CM \& Sul HS 1998 Understanding adipocyte differentiation. Physiological Reviews 78 783-809.

Ham JN, Crutchlow MF, Desai BM, Simmons R \& Stoffers D 2009 Exendin-4 normalizes islet vascularity in intrauterine growth restricted rats: potential role of VEGF. Pediatric Research 66 42-46. (doi:10.1203/PDR.0b013e3181a282a5)

Hanson RW \& Reshef L 1997 Regulation of phosphoenolpyruvate carboxylase (GTP) gene expression. Annual Review of Biochemistry 66 581-611. (doi:10.1146/annurev.biochem.66.1.581)

Harbuz MS \& Lightman SL 1989 Glucocorticoid inhibition of stressinduced changes in hypothalamic corticotrophin-releasing factor messenger RNA and proenkephalin A messenger RNA. Neuropeptides 14 17-20. (doi:10.1016/0143-4179(89)90029-2)

Heinrichs SC \& Richard D 1999 The role of corticotropin-releasing factor and urocortin in the modulation of ingestive behaviour. Neuropeptides 33 350-359. (doi:10.1054/npep.1999.0047)

Heszele MFC \& Price SR 2004 Insulin-like growth factor I: the yin and yang of muscle atrophy. Endocrinology 145 4803-4805. (doi:10.1210/ en.2004-1037)

Holness MJ, Langdown ML \& Sugden MC 2000 Early-life programming of susceptibility to dysregulation of glucose metabolism and the development of Type 2 diabetes mellitus. Biochemical Journal $\mathbf{3 4 9}$ 657-665. (doi:10.1042/bj3490657)

Hudson JI, Hudson MS, Rothschild AJ, Vignati L, Schatzberg AF, \& Melby JC 1984 Abnormal results of dexamethasone suppression tests in non-depressed patients with diabetes mellitus. Archives of General Psychiatry 41 1086-1089. (doi:10.1001/ archpsyc.1983.01790220076012)

Islam A, Chen I, Poth M, Smith ZP \& Deuster PA 2012 Glucocorticoid receptor density correlates with health risk factors and insulin resistance

http://joe.endocrinology-journals.org

DOI: $10.1530 / \mathrm{JOE}-16-0118$
๑ 2016 Society for Endocrinology Printed in Great Britain in Caucasian and African American subjects. Experimental and Clinical Endocrinology and Diabetes 120 477-481. (doi:10.1055/s-0032-1321809)

John CD, Sahni V, Mehet D, Morris JF, Christian HC, Perretti M, Flower RJ, Solito E \& Buckingham JC 2007 Formyl peptide receptors and the regulation of ACTH secretion: targets for annexin A1, lipoxins, and bacterial peptides. FASEB Journal 21 1037-1046. (doi:10.1096/fj.06-7299com)

Jung C, Ho JT, Torpy DJ, Rogers A, Doogue M, Lewis JG, Czajko RJ \& Inder WJ 2011 A longitudinal study of plasma and urinary cortisol in pregnancy and postpartum. Journal of Clinical Endocrinology and Metabolism 96 1533-1540. (doi:10.1210/jc.2010-2395)

Kahn SE 2001 The importance of $\beta$-cell failure in the development and progression of type 2 diabetes. Journal of Clinical Endocrinology and Metabolism 86 4047-4058. (doi:10.1210/jcem.86.9.7713)

Kanoski SE, Rupprecht LE, Fortin SM, De Jonghe BC \& Hayes MR $2012 a$ The role of nausea in food intake and body weight suppression by peripheral GLP-1 receptor agonists, exendin-4 and liraglutide. Neuropharmacology 62 1916-1927. (doi:10.1016/ j.neuropharm.2011.12.022)

Kanoski SE, Zhao S, Guarnieri DJ, DiLeone RJ, Yan J, De Jonghe BC, Bence KK, Hayes MR \& Grill HJ 2012b Endogenous leptin receptor signalling in the medial nucleus tractus solitarius affects meal size and potentiates intestinal satiation signals. American Journal of Physiology. Endocrinology and Metabolism 303 E496-E503. (doi:10.1152/ ajpendo.00205.2012)

Keller-Wood M 2015 Hypothalamic-pituitary-adrenal axis-feedback control. Comprehensive Physiology 5 1161-1182. (doi:10.1002/cphy.c140065)

Kinzig KP, D'Alessio D, Herman JP, Sakai RR, Vahl TP, Figueiredo HF, Murphy EK \& Seeley RJ 2003 CNS glucagon-like peptide-1 receptors mediate endocrine and anxiety responses to interoceptive and psychogenic stressors. Journal of Neuroscience 23 6163-6170.

Kuo T, Harris CA \& Wang J-C 2013 Metabolic functions of glucocorticoid receptor in skeletal muscle. Molecular and Cellular Endocrinology 380 79-88. (doi:10.1016/j.mce.2013.03.003)

Lambillotte C, Gilon P \& Henquin JC 1997 Direct glucocorticoid inhibition of insulin secretion: an in vitro study of dexamethasone effects in mouse islets. Journal of Clinical Investigation 99 414-423. (doi:10.1172/JCI119175)

Lantz K, Vatamaniuk MZ, Brestelli JE, Friedman JR, Matschinsky FM \& Kaestner KH 2004 Foxa2 regulates multiple pathways of insulin secretion. Journal of Clinical Investigation 114 512-520. (doi:10.1172/ JCI200421149)

Larsen PJ, Tang-Christensen M, Holst JJ \& Ørskov C 1997 Distribution of glucagon-like peptide-1 and other preproglucagon-derived peptides in the rat hypothalamus and brainstem. Neuroscience 77 257-270. (doi:10.1016/S0306-4522(96)00434-4)

Liu Y, Coello AG, Grinevich V \& Aguilera G 2010 Involvement of transducer of regulated cAMP response element-binding protein activity on corticotropin releasing hormone transcription. Endocrinology 151 1109-1118. (doi:10.1210/en.2009-0963)

Longui CA, Giusti MM, Calliari LE, Katiki T, Kochi C \& Monte O 2003 Partial glucocorticoid resistance in obese children detected by very low dose dexamethasone suppression test. Journal of Pediatric Endocrinology and Metabolism 16 1277-1282. (doi:10.1515/ jpem.2003.16.9.1277)

Malendowicz LK, Nussdorfer G, Nowak KW, Ziolkowska A, Tortorella C \& Trejter M 2003 Exendin-4, a GLP-1 receptor agonist, stimulates pituitary-adrenocortical axis in the rat: investigations into the mechanism(s) underlying Ex4 effect. International Journal of Molecular Medicine 12 237-241. (doi:10.3892/ijmm.12.2.237)

Marshak S, Ben-Shushan E, Shoshkes M, Havin L, Cerasi E \& Melloul D 2001 Regulatory elements involved in human pdx-1 gene expression. Diabetes 50 S37. (doi:10.2337/diabetes.50.2007.S37)

Masuzaki H, Paterson J, Shinyama H, Morton NM, Mullins JJ, Seckl JR \& Flier JS 2001 A transgenic model of visceral obesity and the metabolic syndrome. Science 294 2166-2170. (doi:10.1126/science.1066285) 
Matthes H, Kaiser A, Stier U, Riecken EO \& Rosewicz S 1994 Glucocorticoid receptor gene expression in the exocrine and endocrine rat pancreas. Endocrinology 135 476-479. (doi:10.1210/ endo.135.1.8013388)

Melloul D 2004 Transcription factors in islet development and physiology: role of PDX-1 in beta-cell function. Annals of the New York Academy of Sciences 1014 28-37. (doi:10.1196/ annals.1294.003)

Menacho-Márquez M, Nogueiras R, Fabbiano S, Sauzeau V, Al-Massadi O, Diéguez C \& Bustelo XR 2013 Chronic sympathoexcitation through loss of Vav3, a Rac1 activator, results in divergent effects on metabolic syndrome and obesity depending on diet. Cell Metabolism 18 199-211. (doi:10.1016/j.cmet.2013.07.001)

Merchenthaler I, Lane M \& Shughrue P 1999 Distribution of pre-proglucagon and glucagon-like peptide-1 receptor messenger RNAs in the rat central nervous system. Journal of Comparative Neurology $\mathbf{4 0 3}$ 261-280. (doi:10.1002/(sici)1096-9861(19990111)403:2<261::aidcne8>3.0.co;2-5)

Möller C, Sommer W, Thorsell A, Rimondini R \& Heilig M 2002 Anxiogenic-like action of centrally administered glucagon-like peptide-1 in a punished drinking test. Progress in Neuro-Psychopharmacology and Biological Psychiatry 26 119-122. (doi:10.1016/S0278-5846(01)00223-8)

Moore MC, Connolly CC \& Cherrington D 1998 Autoregulation of hepatic glucose production. European Journal of Endocrinology 138 240-248. (doi:10.1530/eje.0.1380240)

Morgan SA, McCabe EL, Gatherole LL, Hassan-Smith ZK, Larner DP Bujalska IJ, Stewart PM, Tomlinson JW \& Lavery GG 2014 11 $\beta$-HSD1 is the major regulator of the tissue-specific effects of circulating glucocorticoid excess. PNAS 111 E2482-E2491. (doi:10.1073/ pnas.1323681111)

Nakade Y, Tsukamoto K, Pappas TN \& Takahashi T 2006 Central glucagon like peptide- 1 delays solid gastric emptying via central CRF and peripheral sympathetic pathway in rats. Brain Research 1111 117-121. (doi:10.1016/j.brainres.2006.06.090)

Navarro M, De Fonseca FR, Alvarez E, Chowen JA, Zueco JA, Gomez R, Eng J \& Blázquez E 1996 Colocalization of glucagon-like peptide-1 (GLP-1) receptors, glucose transporter GLUT-2, and glucokinase mRNAs in rat hypothalamic cells: evidence for a role of GLP-1 receptor agonists as an inhibitory signal for food and water intake. Journal of Neurochemistry 67 1982-1991. (doi:10.1046/j.14714159.1996.67051982.x)

Nielsen JH, Haase TN, Jaksch C, Nalla A, Søstrup B, Nalla AA, Larsen L, Rasmussen M, Dalgaard LT, Gaarn LW, et al. 2014 Impact of fetal and neonatal environment on beta cell function and development of diabetes. Acta Obstetricia et Gynecologica Scandinavica 93 1109-1122. (doi:10.1111/aogs.12504)

Okamoto S, Kimura K \& Saito M 2001 Anorectic effect of leptin is mediated by hypothalamic corticotropin-releasing hormone, but not by urocortin, in rats. Neuroscience Letters 307 179-182. (doi:10.1016/ S0304-3940(01)01959-0)

Pacak K, Palkovits M, Kopin IJ \& Goldstein DS 1995 Stress-induced norepinephrine release in the hypothalamic paraventricular nucleus and pituitary- adrenocortical and sympathoadrenal activity: in vivo microdialysis studies. Frontiers in Neuroendocrinology 16 89-150. (doi:10.1006/frne.1995.1004)

Park JS, Bae SJ, Choi S-W, Son YH, Park SB, Rhee SD, Kim HY, Jung WH, Kang SK, Ahn JH, et al. 2014 A novel 11 $\beta$-HSD1 inhibitor improves diabesity and osteoblast differentiation. Journal of Molecular Endocrinology 52 191-202. (doi:10.1530/JME-13-0177)

Pasquali R, Vicennati V, Cacciari M \& Pagotto U 2006 The hypothalamicpituitary-adrenal axis activity in obesity and the metabolic syndrome. Annals of the New York Academy of Sciences 1083 111-128. (doi:10.1196/annals.1367.009)

Paulmyer-Lacroix O, Boullu S, Oliver C, Alessi M-C \& Grino M 2002 Expression of the mRNA coding for $11 \beta$-hydroxysteroid

http://joe.endocrinology-journals.org

DOI: $10.1530 / \mathrm{JOE}-16-0118$
(C) 2016 Society for Endocrinology Printed in Great Britain dehydrogenase type 1 in adipose tissue from obese patients: an in situ hybridization study. Journal of Clinical Endocrinology and Metabolism 87 2701-2705. (doi:10.1210/jcem.87.6.8614)

Peckett AJ, Wright DC \& Ridell MC 2011 The effects of glucocorticoids on adipose tissue lipid metabolism. Metabolism Clinical and Experimental 60 1500-1510. (doi:10.1016/j.metabol.2011.06.012)

Pérez-Tilve D, González-Matías L, Aulinger B, Alvarez-Crespo M, Gil-Lozano M, Alvarez E, Andrade-Olivie AM, Tschöp MH, D'Alessio D \& Mallo F 2010 Exendin-4 increases blood glucose levels acutely in rats by activation of the sympathetic nervous system. American Journal of Physiology. Endocrinology and Metabolism 298 E1088-E1096. (doi:10.1152/ajpendo.00464.2009)

Pinney SE, Jaeckle Santos LJ, Han Y, Stoffers DA \& Simmons RA 2011 Exendin- 4 increases histone acetylase activity and reverses epigenetic modifications that silence $\mathrm{Pdx} 1$ in the intrauterine growth retarded rat. Diabetologia 54 2606-2614. (doi:10.1007/s00125-011-2250-1)

Prentki M \& Madiraju SRM 2012 Glycerolipid/free fatty acid cycle and islet b-cell function in health, obesity and diabetes. Molecular and Cellular Endocrinology 353 88-100. (doi:10.1016/j.mce.2011.11.004)

Prpić-Križevac I, Canecki-Varžić S \& Bilić-Ćurčić I 2012 Hyperactivity of the hypothalamic-pituitary-adrenal axis in patients with type 2 diabetes and relations with insulin resistance and chronic complications. Wiener Klinische Wochenschrift 124 403-411. (doi:10.1007/s00508-012-0191-4)

Puthanveetil P, Wang F, Kewalramani G, Kim MS, Hosseini-Beheshti E, Ng N, Lau W, Pulinilkunnil T, Allard M, Abrahani A, et al. 2008 Cardiac glycogen accumulation after dexamethasone is regulated by AMPK. American Journal of Physiology. Heart and Circulatory Physiology 295 H1753-H1762. (doi:10.1152/ajpheart.518.2008)

Quan ZY \& Walser M 1992 Effects of corticosterone administration on nitrogen excretion and nitrogen balance in adrenalectomized rats. American Journal of Clinical Nutrition 55 695-700.

Raab EL, Vuguin PM, Stoffers DA \& Simmons RA 2009 Neonatal exendin- 4 treatment reduces oxidative stress and prevents hepatic insulin resistance in intrauterine growth-retarded rats. American Journal of Physiology. Regulatory, Integrative and Comparative Physiology 297 R1785-R1794. (doi:10.1152/ajpregu.00519.2009)

Reaven GM 1993 Role of insulin resistance in human disease (syndrome $\mathrm{X})$ : an expanded definition. Annual Review of Medicine 44 121-131. (doi:10.1146/annurev.me.44.020193.001005)

Reynolds RM, Labad J, Buss C, Ghaemmaghami P \& Räikkönen K 2013 Transmitting biological effects of stress in utero: implications for mother and offspring. Psychoneuroendocrinology 38 1843-1849. (doi:10.1016/j.psyneuen.2013.05.018)

Richard JE, Farkas I, Anesten F, Anderberg RH, Dickson SL, Gribble FM, Reimann F, Jansson J-O, Liposits Z \& Skibicka KP 2014 GLP-1 Receptor stimulation of the lateral parabrachial nucleus reduces food intake: neuroanatomical, electrophysiological, and behavioral evidence. Endocrinology 155 4356-4367. (doi:10.1210/en.2014-1248)

Richard JE, Anderberg RH, Göteson A, Gribble FM, Reimann F \& Skibicka KP 2015 Activation of the GLP-1 receptors in the nucleus of the solitary tract reduces food reward behaviour and targets the mesolimbic system. PLoS ONE 10 e0119034. (doi:10.1371/journal. pone.0119034)

Rinaman L 1999 Interoceptive stress activates glucagon-like peptide-1 neurons that project to the hypothalamus. American Journal of Physiology 277 R582-R590.

Ritter S \& Taylor JS 1990 Vagal sensory neurons are required for lipoprivic but not glucoprivic feeding in rats. American Journal of Physiology. Regulatory, Integrative and Comparative Physiology $\mathbf{2 5 8}$ R1395-R1401.

Rowland NE, Crews EC \& Gentry RM 1997 Comparison of Fos induced in rat brain by GLP-1 and amylin. Regulatory Peptides 71 171-174. (doi:10.1016/S0167-0115(97)01034-3)

Saad MJ, Folli F, Kahn JA \& Kahn CR 1993 Modulation of insulin receptor, insulin receptor substrate-1, and phosphatidylinositol 
3-kinase in liver and muscle of dexamethasone-treated rats. Journal of Clinical Investigation 92 2065-2072. (doi:10.1172/JCI116803)

Sakoda H, Ogihara T, Anai M, Funaki M, Inukai K, Katagiri H, Fukushima Y, Onishi Y, Ono H, Fujishiro M, et al. 2000 Dexamethasone-induced insulin resistance in 3T3-L1 adipocytes is due to inhibition of glucose transport rather than insulin signal transduction. Diabetes 49 1700-1708. (doi:10.2337/diabetes.49.10.1700)

Saltiel AR \& Kahn CR 2001 Insulin signalling and the regulation of glucose and lipid metabolism. Nature 414 799-806. (doi:10.1038/414799a)

Sancho V, Trigo MV, Martín-Duce A, Gonzalez N, Acitores A, Arnés L, Valverde I, Malaisse W \& Villanueva-Peñacarrillo M 2006 Effect of GLP-1 on D-glucose transport, lipolysis and lipogenesis in adipocytes of obese subjects. International Journal of Molecular Medicine $\mathbf{1 7}$ 1133-1137. (doi:10.3892/ijmm.17.6.1133)

Sarkar S, Fekete C, Légrádi G \& Lechan RM 2003 Glucagon like peptide-1 (7-36) amide (GLP-1) nerve terminals densely innervate corticotropin-releasing hormone neurons in the hypothalamic paraventricular nucleus. Brain Research 985 163-168. (doi:10.1016/ S0006-8993(03)03117-2)

Sasaki K, Cripe TP, Koch SR, Andreone TL, Petersen DD, Beale EG \& Granner DK 1984 Multihormonal regulation of phosphoenolpyruvate carboxykinase gene transcription. The dominant role of insulin. Journal of Biological Chemistry 259 15242-15251.

Schwartz MW, Seeley RJ, Campfield LA, Burn P \& Baskin DG 1996 Identification of targets of leptin action in rat hypothalamus. Journal of Clinical Investigation 98 1101-1106. (doi:10.1172/JCI118891)

Seeley RJ, Blake K, Rushing PA, Benoit S, Eng J, Woods SC \& D'Alessio D 2000 The role of CNS glucagon-like peptide-1 (7-36) amide receptors in mediating the visceral illness effects of lithium chloride. Journal of Neuroscience 20 1616-1621.

Sewell MF, Huston-Presley L, Super DM \& Catalano P 2006 Increased neonatal fat mass, not lean body mass, is associated with maternal obesity. American Journal of Obstetrics and Gynecology 195 1100-1103. (doi:10.1016/j.ajog.2006.06.014)

Shahkhalili Y, Moulin J, Zbinden I, Aprikian O \& Macé K 2010 Comparison of two models of intrauterine growth restriction for early catch-up and later development of glucose intolerance and obesity in rats. American Journal of Physiology. Regulatory, Integrative and Comparative Physiology 298 R141-R146. (doi:10.1152/ ajpregu.00128.2009).

Shao S, Fang Z, Yu X \& Zhang M 2009 Transcription factors involved in glucose-stimulated insulin secretion of pancreatic beta cells. Biochemical and Biophysical Research Communications 384 401-404. (doi:10.1016/j.bbrc.2009.04.135)

Sharma AN, Wigham J \& Veldhuis JD 2014 Corticotropic axis drive of overnight cortisol secretion is suppressed in adolescents and young adults with type 1 diabetes mellitus. Pediatric Diabetes 15 444-452. (doi:10.1111/pedi.12108)

Shen C-N, Seckl JR, Slack JMW \& Tosh D 2003 Glucocorticoids suppress beta-cell development and induce hepatic metaplasia in embryonic pancreas. Biochemical Journal 375 41-50. (doi:10.1042/ bj20030140)

Shibli-Rahhal A, Van Beek M \& Schlechte JA 2006 Cushing's syndrome. Clinics in Dermatology 24 260-265. (doi:10.1016/j. clindermatol.2006.04.012)

Simmons RA, Templeton LJ \& Gertz SJ 2001 Intrauterine growth retardation leads to the development of type 2 diabetes in the rat. Diabetes 50 2279-2286. (doi:10.2337/diabetes.50.10.2279)

Skibicka KP 2013 The central GLP-1: implications for food and drug reward. Frontiers in Neuroscience 7 181. (doi:10.3389/ fnins.2013.00181)

Slavin BG, Onq JM \& Kern PA 1994 Hormonal regulation of hormonesensitive lipase activity and mRNA levels in isolated rat adipocytes. Journal of Lipid Research 35 1535-1541.

Smith AG \& Muscat GEO 2005 Skeletal muscle and nuclear hormone receptors: implications for cardiovascular and metabolic disease.
International Journal of Biochemistry and Cell Biology 37 2047-2063. (doi:10.1016/j.biocel.2005.03.002)

Srinivasan M, Karewa SD, Palaniyappan A, Pandya JD \& Patel MS 2006 Maternal high-fat diet consumption results in fetal programming predisposing to the onset of metabolic syndrome-like phenotype in adulthood. American Journal of Physiology. Endocrinology and Metabolism 291 E792-E799. (doi:10.1152/ajpendo.00078.2006)

Stoffers D, Desai BM, DeLeon DD \& Simmons R 2003 Neonatal exendin-4 prevents the development of diabetes in the intrauterine growth retarded rat. Diabetes 52 734-740. (doi:10.2337/diabetes.52.3.734)

Tachibana T, Sato M, Oikawa D \& Furuse M 2006 Involvement of CRF on the anorexic effect of GLP-1 in layer chicks. Comparative Biochemistry and Physiology. Part A, Molecular \& Integrative Physiology 143 112-117. (doi:10.1016/j.cbpa.2005.11.007)

Tang-Christensen M 1996 Central administration of GLP-1 (7-36) amide inhibits food and water intake in rats. American Journal of Physics 271 848-856.

Tang-Christensen M, Larsen PJ, Thulesen J, Romer J \& Vrang N 2000 The proglucagon-derived peptide, glucagon-like peptide-2, is a neurotransmitter involved in the regulation of food intake. Nature Medicine 6 802-807. (doi:10.1038/77535)

Thiele TE 1997 Central infusion of GLP-1, but not leptin, produces conditioned taste aversions in rats. American Journal of Physiology $\mathbf{2 7 2}$ R726-R730.

Thiele TE, van Dijk G, Yagaloff KA, Fisher SL, Schwartz M, Burn P \& Seeley RJ 1998 Central infusion of melanocortin agonist MTII in rats: assessment of c-Fos expression and taste aversion. American Journal of Physiology. Regulatory, Integrative and Comparative Physiology 274 R248-R254.

Topp BG, Atkinson LL \& Finegood DT 2007 Dynamics of insulin sensitivity, $\beta$-cell function, and $\beta$-cell mass during the development of diabetes in $\mathrm{fa} / \mathrm{fa}$ rats. American Journal of Physiology. Endocrinology and Metabolism 293 E1730-E1735. (doi:10.1152/ ajpendo.00572.2007)

Turton MD 1996 A role for glucagon-like peptide-1 in the central regulation of feeding. Nature 379 69-72. (doi:10.1038/379069a0)

Uchoa ET, Aguilera G, Herman JP, Fiedler JL, Deak T \& de Sousa MBC 2014 Novel aspects of glucocorticoid actions. Journal of Neuroendocrinology 26 557-572. (doi:10.1111/jne.12157)

Valtat B, Riveline JP, Zhang P, Singh-Estivalet A, Armanet M, Venteclef N, Besseiche A, Kelly DP, Tronche F, Ferré P, et al. 2013 Fetal PGC-1 $\alpha$ overexpression programs adult pancreatic $\beta$-cell dysfunction. Diabetes 62 1206-1216. (doi:10.2337/db12-0314)

van Bloemendaal L, IJzerman RG, ten Kulve JS, Barkhof F, Konrad RJ, Drent ML, Veltman DJ \& Diamant M 2014 GLP-1 receptor activation modulates appetite- and reward-related brain areas in humans. Diabetes 63 4186-4196. (doi:10.2337/db14-0849)

van den Berghe G 1991 The role of the liver in metabolic homeostasis: implications for inborn errors of metabolism. Journal of Inherited Metabolic Disease 14 407-420. (doi:10.1007/BF01797914)

van Dijk G 1996 Central infusions of leptin and GLP-1-(7-36) amide differentially stimulate c-FLI in the rat brain. American Journal of Physiology 271 R1096-R1100.

van Dijk G, Thiele TE, Seeley RJ, Woods SC \& Bernstein IL 1997 Glucagon-like peptide 1 and satiety. Nature 385214. (doi:10.1038/385214a0)

van Raalte DH \& Diamant M 2011 Glucolipotoxicity and beta cells in type 2 diabetes mellitus: target for durable therapy? Diabetes Research and Clinical Practice 93 S37-S46. (doi:10.1016/S01688227(11)70012-2)

van Raalte DH, Ouwens DM \& Diamant M 2009 Novel insights into glucocorticoid-mediated diabetogenic effects: towards expansion of therapeutic options? European Journal of Clinical Investigation 39 81-93. (doi:10.1111/j.1365-2362.2008.02067.x)

Vegiopoulos A \& Herzig S 2007 Glucocorticoids, metabolism and metabolic diseases. Molecular and Cellular Endocrinology 275 43-61. (doi:10.1016/j.mce.2007.05.015) 
Vermes I, Steinmetz E, Schoorl J, van Der Veen EA \& Tilders FJH 1985 Increased plasma levels of immunoreactive $\beta$-endorphin and corticotropin in non-insulin-dependent diabetes. Lancet $\mathbf{3 2 6}$ 725-726. (doi:10.1016/S0140-6736(85)92964-2)

Vrang N, Hansen M, Larsen PJ \& Tang-Christensen M 2007 Characterization of brainstem preproglucagon projections to the paraventricular and dorsomedial hypothalamic nuclei. Brain Research 1149 118-126. (doi:10.1016/j.brainres.2007.02.043)

Wang M 2011 Inhibitors of $11 \beta$-hydroxysteroid dehydrogenase type 1 in antidiabetic therapy. In Diabetes - Perspectives in Drug Therapy SE - 6, pp 127-146. Ed M Schwanstecher. Berlin, Heidelberg, Germany: Springer Berlin Heidelberg. (doi:10.1007/978-3-64217214-4_6)

Weinstein SP, Paquin T, Pritsker A \& Haber RS 1995 Glucocorticoidinduced insulin resistance: dexamethasone inhibits the activation of glucose transport in rat skeletal muscle by both insulin- and non-insulin-related stimuli. Diabetes 44 441-445. (doi:10.2337/ diab.44.4.441)

Wu Y, Barrett EJ, Long W \& Liu Z 2004 Glucocorticoids differentially modulate insulin-mediated protein and glycogen synthetic signalling downstream of protein kinase B in rat myocardium. Endocrinology 145 1161-1166. (doi:10.1210/en.2003-1429)

Yamamoto H, Lee CE, Marcus JN, Williams TD, Overton JM, Lopez ME, Hollenberg AN, Baggio L, Saper CB, Drucker DJ, et al. 2002 Glucagon-like peptide-1 receptor stimulation increases blood pressure and heart rate and activates autonomic regulatory neurons. Journal of Clinical Investigation 110 43-52. (doi:10.1172/JCI15595)

Yamamoto H, Kishi T, Lee CE, Choi BJ, Fang H, Hollenberg AN, Drucker DJ \& Elmquist JK 2003 Glucagon-like peptide-1-responsive catecholamine neurons in the area postrema link peripheral glucagon-like peptide-1 with central autonomic control sites. Journal of Neuroscience 23 2939-2946.

Zhang R, Packard BA, Tauchi M, D’Alessio DA \& Herman JP 2009 Glucocorticoid regulation of preproglucagon transcription and RNA stability during stress. PNAS 106 5913-5918. (doi:10.1073/ pnas.0808716106)

Zhang R, Jankord R, Flak JN, Solomon MB, D'Alessio DA \& Herman JP 2010 Role of glucocorticoids in tuning hindbrain stress integration. Journal of Neuroscience 30 14907-14914. (doi:10.1523/ JNEUROSCI.0522-10.2010)

Received in final form 26 May 2016

Accepted 20 June 2016

Accepted Preprint published online 20 June 2016
(C) 2016 Society for Endocrinology Printed in Great Britain
Published by Bioscientifica Ltd 